\title{
Estimation of Heterosis, Heterobeltiosis and Economic Heterosis in Dual Purpose Sorghum [Sorghum bicolor (L.) Moench]
}

\author{
B.L. Meena ${ }^{1}$, B.R. Ranwah $^{2}$, S.P. Das, S.K. Meena, R. Kumari, \\ Rumana Khan, V.K. Bhagasara and A. Gangarani Devi \\ ${ }^{1}$ ICAR Research Complex for NEH Region, Tripura Centre, Lembucherra - 799210, India \\ ${ }^{2}$ MPUAT, Rajasthan College of Agriculture, Udaipur Rajasthan -313001, India \\ *Corresponding author
}

\section{A B S T R A C T}

The present investigation was under taken for 10 lines and 3 tester using line $\mathrm{x}$ tester mating design consisted of 46 entries including 10 lines, 3 testers, 30 hybrids and three checks viz., CSV 23, CSV 27 and CSH25. These were evaluated in RBD with three replications during kharif 2015 in four environments created by using different spacing viz., $22.5 \times 5 \mathrm{~cm}\left(\mathrm{E}_{1}\right), 30 \times 10 \mathrm{~cm}\left(\mathrm{E}_{2}\right), 45 \times 10 \mathrm{~cm}\left(\mathrm{E}_{3}\right)$ and $60 \times 10 \mathrm{~cm}\left(\mathrm{E}_{4}\right)$ at Instructional farm Rajasthan college of Agriculture, Udaipur in randomized block design with three replications. Some of the parents out crossed the limit of best checks for dry fodder yield, green fodder yield, protein content in grain and protein content in fodder in one or other environments. 24 crosses exhibited economic heterosis. Therefore these crosses may be identified as superior crosses for these characters. Significance of line, tester and line $\mathrm{x}$ tester mean square revealed that both additive as well as non additive variance were important in the inheritance of these characters. The contribution of line $x$ testers sum of square was maximum in most of the characters in most of the environments. Three crosses $\mathrm{L}_{2} \times \mathrm{T}_{3}, \mathrm{~L}_{6} \times \mathrm{T}_{3}$ and $\mathrm{L}_{1} \times \mathrm{T}_{3}$ having economic heherosis for grain yield in $\mathrm{E}_{2}$. Where cross $L_{2} \times T_{3}$ and $L_{6} \times T_{3}$ also having economic heterosis for dry fodder yield in $E_{2}$. These crosses had good SCA effects and involving at least one good general combiner parent. This indicates superiority of $\mathrm{F}_{1}$ on account of accumulation of dominant genes. Finaly two dual purpose crosses ICSA $29004 \times \mathrm{SPV} 1822\left(\mathrm{~L}_{2} \times \mathrm{T}_{3}\right)$ and ICSA $29012 \times$ SPV $1822\left(\mathrm{~L}_{6} \times \mathrm{T}_{3}\right)$ were identified for multi location testing as these were having economic heterosis more than 15 per cent for grain yield and dry fodder yield, good SCA, involving one good GCA parents, nicking in flowering in normal spacing environment and male parent taller than the female parent. Apart from above, grain purpose cross ICSA $29003 \times \mathrm{SPV} 1822\left(\mathrm{~L}_{1} \times \mathrm{T}_{3}\right)$ is also identified for multi location testing as it had very high economic heterosis for grain yield $(56.65 \%)$ in medium spacing environment i.e. 30 × 10 $\mathrm{cm}$ along with good nicking in flowering and taller male parent. This cross (ICSB $29003 \times$ SPV 1822) also recommended for selection of transgressive segregants in segregating generations as this cross also having good SCA and involved both good general combiner parents.

\section{Introduction}

Sorghum bicolor (L.) Moench $(2 \mathrm{n}=20)$, family poaceae is one of the most important crops in the world because of its adaptation to a wide range of ecological conditions, 
suitability for low input cultivation and diverse uses (Doggett, 1988). Sorghum occupies fifth position after wheat, rice, maize and barley at world level, both in area and production. The crop is widely grown for food, feed, fodder, forage and fuel in the semi-arid tropics (SAT) of Asia, Africa, America and Australia. It occupies $58.20 \mathrm{~m}$ ha area in the world with an annual grain production of $68.87 \mathrm{~m}$ tones and productivity of $1535 \mathrm{~kg} / \mathrm{ha}$ (FAO, 2015). In India, it covers about $5.82 \mathrm{~m}$ ha with an annual grain production of $5.39 \mathrm{~m}$ tonnes and productivity of $926 \mathrm{~kg} / \mathrm{ha}$ (FAO, 2015). India is largest producer of sorghum in the world (FAO, 2015). The major sorghum growing states in India are Maharashtra, Karnataka, Madhya Pradesh, Andhra Pradesh, Rajasthan, Tamil Nadu, Uttar Pradesh and Gujarat. Area under sorghum reduced a large since independence.

Sorghum green fodder is one of the cheapest sources of feed for milch, meat and draft animals. Among the cereals, sorghum plays an important role being grain cum fodder crop. Mainly three type of sorghum is cultivated i.e. grain, fodder and multicut sorghum. Grain sorghum is having low plant height and high harvest index, fodder sorghum having tall plants and multicut is leafy, thin stem and more tillering ability. The multicut sorghum fulfills the requirement of green fodder particularly during summer but needs irrigation facilities. The grain and fodder sorghum mainly cultivated in rainy season in north India and in both rainy and post rainy in south India. In Rajasthan area under grain sorghum is very low.

L $x$ T mating designs was used the estimation for heterosis, heterobeltiosis and economic heterosis in present investigation and information to be derived.

Maintenance of plant population in per unit area is very difficult. Buffering ability of the genotypes is the only way to cope up with the available space. Therefore, breeding for buffering ability is another important aspect in genetic improvement of crop plants. Development of such a hybrid/variety, which gives a constant and desirable performance over wide range of spacing, is needed. For this, it is desirable to see the impact of various spacing on the yield of sorghum genotypes and identification of genotypes having buffering ability.

Hybrid vigor and its commercial exploitation have paid rich dividends in kharif sorghum leading to quantum jump in sorghum production. However, still it is far below in comparison to maize and pearl millet therefore there is a need for critical studies on combining ability and heterosis involving diverse source of male sterile lines and $\mathrm{R}$ lines.

In view of the above facts, present investigation entitled heterosis, heterobeltiosis and economic heterosis analysis in Dual Purpose Sorghum [Sorghum bicolor (L.) Moench] has been planned and genotypes were evaluated during kharif, 2014 and kharif, 2015 at Instructional Farm, Rajasthan college of Agriculture,

\section{Materials and Methods}

The present investigation entitled "heterosis, heterobeltiosis and economic heterosis analysis in dual purpose sorghum [Sorghum bicolor (L.) Moench]' was conducted at Instructional farm, Rajasthan College of Agriculture, Udaipur during kharif 2014 and kharif 2015. To met out the objectives. The study was completed through Line $\mathrm{x}$ Tester mating designs.

Geographically Instructional Farm is situated at $24^{\circ}-35^{\prime}$ North latitude and $73^{\circ}-42^{\prime}$ East longitude. The elevation of institution farm is 582.17 meters above mean sea level. The 
climatic conditions of the area represent subtropical condition with humid climate. The soil of experimental fields was clay loam, deep, well drained, alluvial in origin and having fairly good moisture holding capacity. On the basis of days to flowering and suitability for dual purpose 36 lines were received from ICRISAT. After evaluation at this station 10 lines were identified on the basis of nicking of flowering. Three testers were identified on the basis of availability of restorer gene and past performance. Checks CSV 23, CSV 27 and CSH 25 were national checks in coordinated trials.

The experimental material comprised of 10 male sterile lines viz., ICSA 29003( $\mathrm{L}_{1}$ ), ICSA $29004\left(\mathrm{~L}_{2}\right)$, ICSA $29006\left(\mathrm{~L}_{3}\right)$, ICSA 29010 (L4), ICSA 29011( $\left.\mathrm{L}_{5}\right)$, ICSA $29012\left(\mathrm{~L}_{6}\right)$, ICSA $29013\left(\mathrm{~L}_{7}\right)$, ICSA $29014\left(\mathrm{~L}_{8}\right)$, ICSA 29015 ( $\mathrm{L}_{9}$ ) and ICSA 29016 ( $\left.\mathrm{L}_{10}\right)$, three restorer testers viz., SPV $245\left(\mathrm{~T}_{1}\right)$, SPV 1430 $\left(\mathrm{T}_{2}\right)$ and SPV $1822\left(\mathrm{~T}_{3}\right)$ and three checks viz. CSV 23, CSV 27, and CSH 25. These 10 lines and three testers were crossed in factorial fashion to obtain the 30 hybrids. The crossing programme was attempted at Udaipur during kharif 2014 and at Warangal during rabi 2014-15.In this experiment total 46 genotypes (10 lines, 3 testers, 30 crosses and 3 checks) were grown in a randomized block design with three replications in four different environments during kharif 2015 at Instructional farm, Rajasthan College of Agriculture, Udaipur (Rajasthan). Each genotype was sown in a single row plot of 2 meter length maintaining a separate crop geometry (spacing) for each environments. The row to row and plant to plant spacing was $22.5 \mathrm{~cm} \times 5 \mathrm{~cm}, 30 \mathrm{~cm} \times 10 \mathrm{~cm}, 45 \mathrm{~cm} \times 10$ $\mathrm{cm}$ and $60 \mathrm{~cm} \times 10 \mathrm{~cm}$ in $E_{1}, E_{2}, E_{3}$ and $E_{4}$, respectively. Observations were recorded on days to $50 \%$ flowering, days to maturity, plant height $(\mathrm{cm})$, green fodder yield $\left(\mathrm{q} \mathrm{ha}^{-1}\right)$, dry fodder yield $\left(\mathrm{q} \mathrm{ha}^{-1}\right)$, stay greenness $(0-1$ scale), ear head length $(\mathrm{cm})$, number of primaries per plant, number of seeds per primaries, seed index, harvest index (\%),grain yield $\left(\mathrm{q} \mathrm{ha}{ }^{-1}\right)$, protein content in fodder $(\%)$ and protein content in grain $(\%)$. To record different observation five competitive plants in each plot were tagged at random. Plot means of all the characters were subjected to various statistical analysis except stay greenness.

\section{Analysis of variance}

The plot means of each character were subjected to analysis of variance for individual environment as well as over the environment where error variance in different environment were homogeneous using least square technique of Fisher (1932).

\section{Heterosis, heterobeltiosis and economic heterosis}

Heterosis is expressed as per cent deviation from mid parent, whereas heterobeltiosis and economic heterosis, expressed as per cent deviation toward desirable direction over better parent and standard check, respectively. Heterosis, heterobeltiosis and economic heterosis were calculated according to the method suggested by Shull (1914), Fonseca and Patterson (1968) and Meredith and Bridge (1972), respectively for individual as well as over the environments where mean square due to crosses were significant. Whereas, over the environment heterosis was calculated where error variance was homogeneous and mean square due to crosses were significant.

$$
\text { Heterosis }(\%)=\frac{\overline{F_{1}}-\overline{M P}}{\overline{M P}} \times 100
$$


It's significance was tested by using student ' $t$ ' test.

$$
\begin{gathered}
t_{E D F}=\frac{\overline{F_{1}}-\overline{M P}}{S E_{\left(\overline{F_{1}}-\overline{M P}\right)}} \\
S E_{\left(\overline{F_{1}}-\overline{M P}\right)}=\sqrt{\frac{3 M S E}{2 n}} \\
\text { Heterobelt iosis }(\%)=\frac{\left(\overline{F_{1}}-\overline{B P}\right)}{\overline{B P}} \times 100
\end{gathered}
$$

It's significance was tested by using student ' $t$ ' test.

$$
\begin{gathered}
t_{E D F}=\frac{\overline{F_{1}}-\overline{B P}}{S E_{\left(\overline{F_{1}}-\overline{B P}\right)}} \\
S E_{\left(\overline{F_{1}}-\overline{B P}\right)}=\sqrt{\frac{2 M S E}{n}}
\end{gathered}
$$

Economic heterosis:

$$
\text { Economic heterosis }(\%)=\frac{\left(\overline{F_{1}}-\overline{B C}\right)}{\overline{B C}} \times 100
$$

It's significance was tested by using student ' $t$ ' test.

$$
\begin{gathered}
t_{E D F}=\frac{\overline{F_{1}}-\overline{B C}}{S E_{\left(\overline{F_{1}}-\overline{B C}\right)}} \\
S E_{\left(\overline{F_{1}}-\overline{B C}\right)}=\sqrt{\frac{2 M S E}{n}}
\end{gathered}
$$

Where,

$$
\begin{aligned}
\overline{F_{1}} & =\text { Mean value of hybrid } \\
\overline{M P} & =\text { Mean of two corresponding parents, } \mathrm{F}_{1, \mathrm{~s}} \text { i.e. }\left(\mathrm{P}_{1}+\mathrm{P}_{2}\right) / 2 \\
\overline{B P} & =\text { Mean value of better parent } \\
\overline{B C} & =\text { Mean value of best check } \\
\mathrm{N} & =\text { Divisor in respective conditions i.e. } \mathrm{r} \text { in case of individual environment } \\
& \text { and rs in case of over the environments. }
\end{aligned}
$$


$\mathrm{r}, \mathrm{s}=$ Number of replications and environments, respectively.

MS = Error mean square from (Table 7 and 8) for individual and over the

E environments, respectively.

$\mathrm{t}_{\mathrm{EDF}}=$ Student's ' $\mathrm{t}$ ' at error degree of freedom

To calculate heterobeltiosis and economic heterosis parent and check had higher mean values were considered desirable for all the characters except traits like days to 50 per cent flowering and days to maturity where lower mean value was considered desirable and both heterobeltiosis and economic heterosis were calculated in desirable directions only.

\section{Results and Discussion}

The magnitude of heterosis expressed as per cent increase or decrease of $F_{1}$ value over mid parent (relative heterosis), superiority over better parent (heterobeltiosis) and standard check (standard heterosis or economic heterosis) for various trait under different environments and pooled over the environment are presented in table 1 to 13 . The character wise results are summarized in following paragraphs:

\section{Days to 50 flowering}

Analysis of variances revealed significant difference between crosses in all the four environments. The mean square parents vs crosses were significant in $\mathrm{E}_{1}, \mathrm{E}_{2}, \mathrm{E}_{3}$ and $\mathrm{E}_{4}$. Heterosis ranged from -26.71 $\left(\mathrm{L}_{4} \times \mathrm{T}_{2}\right)$ to 6.98 per cent $\left(\mathrm{L}_{5} \times \mathrm{T}_{3}\right)$ in $\mathrm{E}_{1},-17.59\left(\mathrm{~L}_{8} \times \mathrm{T}_{2}\right)$ to 12.20 per cent $\left(\mathrm{L}_{3} \times \mathrm{T}_{3}\right)$ in $\mathrm{E}_{2},-15.70\left(\mathrm{~L}_{6} \mathrm{X}\right.$ $\left.\mathrm{T}_{2}\right)$ to 2.00 per cent $\left(\mathrm{L}_{3} \times \mathrm{T}_{3}\right)$ in $\mathrm{E}_{3}$ and -17.95 $\left(\mathrm{L}_{8} \times \mathrm{T}_{3}\right)$ to 16.06 per cent $\left(\mathrm{L}_{5} \times \mathrm{T}_{2}\right)$ in $\mathrm{E}_{4}$. The negative heterosis was significant for 4 $\left(\mathrm{E}_{1}\right), 15\left(\mathrm{E}_{2}\right), 15\left(\mathrm{E}_{3}\right)$ and $5\left(\mathrm{E}_{4}\right)$ crosses and positive for $3\left(E_{2}\right)$ and $5\left(E_{4}\right)$ crosses.

Heterobeltiosis was estimated for earliness. It was significant for 4, 12, 15 and 2 crosses in $\mathrm{E}_{1}, \mathrm{E}_{2}, \mathrm{E}_{3}$ and $\mathrm{E}_{4}$, respectively. The highest magnitude of heterobeltiosis was $-24.55\left(\mathrm{~L}_{4} \mathrm{X}\right.$ $\left.\mathrm{T}_{2}\right)$, -16.82( $\left.\mathrm{L}_{8} \times \mathrm{T}_{2}\right),-15.38\left(\mathrm{~L}_{8} \times \mathrm{T}_{1}\right)$ and $14.15\left(\mathrm{~L}_{8} \times \mathrm{T}_{3}\right)$ per cent in $\mathrm{E}_{1}, \mathrm{E}_{2}, \mathrm{E}_{3}$ and $\mathrm{E}_{4}$, respectively. Cross $\mathrm{L}_{8} \times \mathrm{T}_{2}$ had consistent significant heterobeltiosis in $\mathrm{E}_{1}, \mathrm{E}_{2}$, and $\mathrm{E}_{3}$ environments and $L_{8} \times T_{3}$ in $E_{2}, E_{3}$, and $E_{4}$ environments.

The economic heterosis was significant for $\mathrm{L}_{8}$ $\mathrm{x} \mathrm{T}_{1}(-11.94 \%)$ and $\mathrm{L}_{4} \times \mathrm{T}_{2}(-17.41 \%)$ in $\mathrm{E}_{1}$; $\mathrm{L}_{8} \times \mathrm{T}_{1}(-8.28 \%)$ in $\mathrm{E}_{2}$ and $\mathrm{L}_{2} \times \mathrm{T}_{1}(-8.22 \%)$, $\mathrm{L}_{4} \times \mathrm{T}_{1}(-10.96 \%), \mathrm{L}_{5} \times \mathrm{T}_{1}(-5.94 \%), \mathrm{L}_{7} \times \mathrm{T}_{1}$ (-10.05\%), $\mathrm{L}_{8} \times \mathrm{T}_{1}(-14.61 \%), \mathrm{L}_{9} \times \mathrm{T}_{1}(-5.48$ $\%), \mathrm{L}_{5} \times \mathrm{T}_{2}(-9.59 \%), \mathrm{L}_{6} \times \mathrm{T}_{2}(-14.16 \%), \mathrm{L}_{8}$ $\mathrm{x} \mathrm{T}_{2}(-14.16 \%), \mathrm{L}_{10} \times \mathrm{T}_{2}(-7.31 \%), \mathrm{L}_{4} \times \mathrm{T}_{3}(-$ $10.05 \%), \mathrm{L}_{6} \times \mathrm{T}_{3}(-5.94 \%), \mathrm{L}_{7} \times \mathrm{T}_{3}(-9.13 \%)$ and $\mathrm{L}_{8} \times \mathrm{T}_{3}(-13.24 \%)$ in $\mathrm{E}_{3}$ (Table 1).

\section{Days to maturity}

Analysis of variances revealed significant difference between crosses in all the four environments. The $\mathrm{P} \mathrm{Vs} \mathrm{C}$ were significant in $\mathrm{E}_{1}, \mathrm{E}_{2}, \mathrm{E}_{3}$ and $\mathrm{E}_{4}$. The magnitude of heterosis ranged from $-11.92\left(\mathrm{~L}_{8} \times \mathrm{T}_{2}\right)$ to 6.10 per cent $\left(\mathrm{L}_{2} \times \mathrm{T}_{2}\right)$ in $\mathrm{E}_{1},-11.53\left(\mathrm{~L}_{10} \times \mathrm{T}_{2}\right)$ to 5.53 per cent $\left(\mathrm{L}_{3} \times \mathrm{T}_{1}\right)$ in $\mathrm{E}_{2},-8.10\left(\mathrm{~L}_{8} \times \mathrm{T}_{1}\right)$ to 7.93 per cent $\left(\mathrm{L}_{3} \times \mathrm{T}_{1}\right)$ in $\mathrm{E} 3$ and $-10.37\left(\mathrm{~L}_{10} \times \mathrm{T}_{2}\right)$ to 5.21 per cent $\left(\mathrm{L}_{2} \times \mathrm{T}_{2}\right)$ in $\mathrm{E}_{4}$. The $15,20,16$ and 17 crosses exhibited significant and negative and 6, 7, 9 and 8 crosses exhibited significant and positive heterosis in $\mathrm{E}_{1}, \mathrm{E}_{2}, \mathrm{E}_{3}$ and $\mathrm{E}_{4}$, respectively.

For early maturity heterobeltiosis was significant for $9,9,9$, and 8 crosses in $\mathrm{E}_{1}, \mathrm{E}_{2}$, $\mathrm{E}_{3}$ and $\mathrm{E}_{4}$, respectively. The highest magnitude of heterobeltiosis was $-7.37\left(\mathrm{~L}_{2} \mathrm{X}\right.$ $\left.\mathrm{T}_{2}\right)$, -6.67 ( $\left.\mathrm{L}_{10} \times \mathrm{T}_{2}\right)$, -6.00 ( $\left.\mathrm{L}_{10} \times \mathrm{T}_{2}\right)$ and $4.75\left(\mathrm{~L}_{7} \mathrm{x} \mathrm{T}_{1}\right)$ in $\mathrm{E}_{1}, \mathrm{E}_{2}, \mathrm{E}_{3}$ and $\mathrm{E} 4$, respectively. Crosses $\mathrm{L}_{10} \times \mathrm{T}_{2}, \mathrm{~L}_{1} \times \mathrm{T}_{3}, \mathrm{~L}_{4} \mathrm{x}$ 
$\mathrm{T}_{3}, \mathrm{~L}_{6} \times \mathrm{T}_{3}, \mathrm{~L}_{7} \times \mathrm{T}_{3}, \mathrm{~L}_{5} \times \mathrm{T}_{1}, \mathrm{~L}_{6} \times \mathrm{T}_{1, \mathrm{~L} 7} \times \mathrm{T}_{1}$ and $\quad \mathrm{L}_{8} \quad \mathrm{x} \quad \mathrm{T}_{1} \quad$ exhibited significant heterobeltiosis in all the four environments and cross $\mathrm{L}_{5} \times \mathrm{T}_{3}$ in $\mathrm{E}_{3}$ and $\mathrm{E}_{4}$. Eonomic heterosis was not significant in any of the cross (Table 2).

\section{Plant height}

Difference between crosses and P Vs C were significant in all the four environments and over the environments. The heterosis ranged from $-18.54\left(\mathrm{~L}_{1} \times \mathrm{T}_{2}\right)$ to 89.83 per cent $\left(\mathrm{L}_{10} \mathrm{X}\right.$ $\left.\mathrm{T}_{1}\right)$ in $\mathrm{E}_{1},-14.16\left(\mathrm{~L}_{7} \mathrm{x} \mathrm{T}_{2}\right)$ to 58.70 per cent $\left(\mathrm{L}_{3} \times \mathrm{T} 3\right)$ in $\mathrm{E}_{2}, 16.85\left(\mathrm{~L}_{2} \times \mathrm{T}_{1}\right)$ to 51.59 per cent $\left(\mathrm{L}_{4} \times \mathrm{T}_{1}\right)$ in $\mathrm{E}_{3}, 16.75\left(\mathrm{~L}_{8} \times \mathrm{T}_{2}\right)$ to 53.24 per cent $\left(\mathrm{L}_{4} \times \mathrm{T}_{1}\right)$ in $\mathrm{E}_{4}$ and $7.64\left(\mathrm{~L}_{2} \times \mathrm{T}_{2}\right)$ to 44.77 per cent $\left(\mathrm{L}_{3} \times \mathrm{T}_{3}\right)$ in pool. The heterosis in negative direction was significant in $\mathrm{E}_{1}$ and $\mathrm{E}_{2}$ in one cross each only. In positive direction it was significant in $16,13,16,17$ and 22 crosses in $\mathrm{E}_{1}, \mathrm{E}_{2}, \mathrm{E}_{3}, \mathrm{E}_{4}$ and pool, respectively. The heterobeltiosis in positive direction was significant for 13, 9, 10, 11 and 19 crosses in $\mathrm{E}_{1} \mathrm{E}_{2}, \mathrm{E}_{3}, \mathrm{E}_{4}$ and pool respectively. The highest magnitude of heterobeltiosis was $62.65\left(\mathrm{~L}_{3} \times \mathrm{T}_{1}\right), 43.13\left(\mathrm{~L}_{2} \times \mathrm{T}_{1}\right), 35.87\left(\mathrm{~L}_{10} \mathrm{x}\right.$ $\left.\mathrm{T}_{1}\right), 44.04\left(\mathrm{~L}_{5} \times \mathrm{T}_{2}\right)$ and $40.16\left(\mathrm{~L}_{10} \times \mathrm{T}_{1}\right)$ in $\mathrm{E}_{1}, \mathrm{E}_{2}, \mathrm{E}_{3}, \mathrm{E}_{4}$ and pool, respectively. Crosses $\mathrm{L}_{5} \times \mathrm{T}_{1}$ and $\mathrm{L}_{10} \times \mathrm{T}_{1}$ in $\mathrm{E}_{1}, \mathrm{E}_{2}, \mathrm{E}_{3}, \mathrm{E}_{4}$ and pool, $\mathrm{L}_{4} \times \mathrm{T}_{1}, \mathrm{~L}_{6} \times \mathrm{T}_{1}, \mathrm{~L}_{5} \times \mathrm{T}_{2}, \mathrm{~L}_{3} \times \mathrm{T}_{3}, \mathrm{~L}_{6} \times \mathrm{T}_{3}$ exhibited significant heterobeltioss in more than three environments, $\mathrm{L}_{3} \times \mathrm{T}_{1}, \mathrm{~L}_{1} \times \mathrm{T}_{3}, \mathrm{~L}_{4} \mathrm{x}$ $\mathrm{T}_{3}, \mathrm{~L}_{5} \times \mathrm{T}_{3}, \mathrm{~L}_{8} \times \mathrm{T}_{3}, \mathrm{~L}_{10} \times \mathrm{T}_{1}$ exhibited significant heterobeltioss in more than two environments. The economic heterosis was significant for 3 and 1 crosses in $E_{2}$ and $E_{3}$ respectively. Crosses exhibited significant economic heterosis were $\mathrm{L}_{3} \times \mathrm{T}_{3}(21.88 \%)$, $\mathrm{L}_{5} \times \mathrm{T}_{3}(18.01 \%)$ and $\mathrm{L}_{7} \times \mathrm{T}_{3}(12.19 \%)$ in $\mathrm{E}_{2}$ and $\mathrm{L}_{6} \times \mathrm{T}_{3}(12.50 \%)$ in $\mathrm{E}_{3}$ (Table 3).

\section{Green fodder yield $\left(\mathrm{q} \mathrm{ha}^{-1}\right)$}

Analysis of variances revealed significant difference between crosses in all the four environments. The P Vs $\mathrm{C}$ were significant in
$E_{2}, E_{3}$ and $E_{4}$. The heterosis ranged from $49.84\left(\mathrm{~L}_{7} \times \mathrm{T}_{1}\right)$ to 103.85 per cent $\left(\mathrm{L}_{9} \times \mathrm{T}_{1}\right)$ in $\mathrm{E}_{1},-58.35\left(\mathrm{~L}_{3} \times \mathrm{T}_{1}\right)$ to 134.65 per cent $\left(\mathrm{L}_{10} \mathrm{x}\right.$ $\left.\mathrm{T}_{3}\right)$ in $\mathrm{E}_{2},-42.24\left(\mathrm{~L}_{6} \times \mathrm{T}_{3}\right)$ to 26.05 per cent $\left(\mathrm{L}_{2} \times \mathrm{T}_{3}\right)$ in $\mathrm{E}_{3}$ and $-49.81\left(\mathrm{~L}_{6} \times \mathrm{T}_{3}\right)$ to 74.61 per cent $\left(\mathrm{L}_{1} \times \mathrm{T}_{2}\right)$ in $\mathrm{E}_{4}$. The 9, 15, 19 and 6 crosses exhibited significant negative and 13 , 8,5 , and 11 crosses exhibited significant \& positive heterosis $\mathrm{E}_{1}, \mathrm{E}_{2}, \mathrm{E}_{3}$ and $\mathrm{E}_{4}$, respectively.

Heterobeltiosis in positive direction was significant for 9,5 and 4 crosses in $E_{1} E_{2}$ and $\mathrm{E}_{4}$ respectively. The highest magnitude of heterobeltiosis was $87.12\left(\mathrm{~L}_{1} \times \mathrm{T}_{3}\right), 76.36\left(\mathrm{~L}_{5}\right.$ $\left.x T_{3}\right)$ and 63.99 per cent $\left(L_{1} \times T_{2}\right)$ in $E_{1}, E_{2}$ and $E_{4}$ respectively. Crosses $L_{1} \times T_{2}$ in $E_{1}$ and $\mathrm{E}_{4}, \mathrm{~L}_{8} \times \mathrm{T}_{2}$ and $\mathrm{L}_{2} \times \mathrm{T}_{3}$ in $\mathrm{E}_{2}$ and $\mathrm{E}_{4}$ and $\mathrm{L}_{5} \mathrm{x}$ $\mathrm{T}_{3}$ in $\mathrm{E}_{1}$ and $\mathrm{E}_{2}$ exhibited significant heterobeltiosis in more than one environment.

Economic heterosis was significant for $\mathrm{L}_{3} \mathrm{x}$ $\mathrm{T}_{3}(20.64 \%), \mathrm{L}_{5} \times \mathrm{T}_{3}(26.81 \%)$ and $\mathrm{L}_{10} \times \mathrm{T}_{3}$ $(17.75 \%)$ in $\left(\mathrm{E}_{2}\right)$ only. Maximum economic heterosis was 26.81 per cent $\left(L_{5} \times T_{3}\right.$ in $\left.E_{2}\right)$ (Table 4).

\section{Dry fodder yield (q ha $\left.{ }^{-1}\right)$}

Analysis of variances revealed significant difference between crosses in all the four environments. The $\mathrm{P}$ Vs $\mathrm{C}$ were significant in $E_{1}, E_{2}, E_{3}$ and $E_{4}$.The heterosis ranged from $58.01\left(\mathrm{~L}_{10} \times \mathrm{T}_{2}\right)$ to 64.84 per cent $\left(\mathrm{L}_{1} \times \mathrm{T}_{2}\right)$ in $\mathrm{E}_{1},-62.77\left(\mathrm{~L}_{6} \times \mathrm{T}_{1}\right)$ to 113.15 per cent $\left(\mathrm{L}_{2} \mathrm{x}\right.$ $\left.\mathrm{T}_{3}\right)$ in $\mathrm{E}_{2},-58.01\left(\mathrm{~L}_{10} \times \mathrm{T}_{2}\right)$ to 61.14 per cent $\left(\mathrm{L}_{1} \times \mathrm{T}_{3}\right)$ in $\mathrm{E}_{3}$ and $-39.52\left(\mathrm{~L}_{8} \times \mathrm{T}_{1}\right)$ to 70.56 per cent $\left(\mathrm{L}_{4} \times \mathrm{T}_{1}\right)$ in $\mathrm{E}_{4}$. The 8, 15, 6 and 7 crosses exhibited significant and negative and $16,9,12$, and 16 crosses exhibited significant and positive heterosis $\mathrm{E}_{1}, \mathrm{E}_{2}, \mathrm{E}_{3}$ and $\mathrm{E}_{4}$, respectively.

Heterobeltiosis in positive direction was significant for 10, 5, 4, and 9 crosses in $E_{1} E_{2}$, $E_{3}$ and $E_{4}$, respectively. The highest 
magnitude of heterobeltiosis was $51.30\left(\mathrm{~L}_{1} \mathrm{x}\right.$ $\left.\mathrm{T}_{2}\right), 61.38\left(\mathrm{~L}_{6} \times \mathrm{T}_{3}\right), 30.56$ per cent $\left(\mathrm{L}_{1} \times \mathrm{T}_{3}\right)$ and 46.03 per cent $\left(\mathrm{L}_{4} \times \mathrm{T}_{1}\right)$ in $\mathrm{E}_{1}, \mathrm{E}_{2}, \mathrm{E}_{3}$ and $\mathrm{E}_{4}$ respectively. Crosses $\mathrm{L}_{3} \times \mathrm{T}_{1}$ in $\mathrm{E}_{3}$ and $\mathrm{E}_{4}$, $\mathrm{L}_{5} \times \mathrm{T}_{1}$ in $\mathrm{E}_{1}$ and $\mathrm{E}_{3}, \mathrm{~L}_{2} \times \mathrm{T}_{2}$ and $\mathrm{L}_{3} \times \mathrm{T}_{2}$ in $\mathrm{E}_{1}$ and $\mathrm{E}_{4}$ exhibited significant heterobeltiosis in more than one environment.

The economic heterosis was significant in $\mathrm{E}_{2}$ only. Crosses exhibited significant economic heterosis in $\mathrm{E}_{2}$ were $\mathrm{L}_{3} \times \mathrm{T}_{3}(16.63 \%)$ and L6 $x \mathrm{~T}_{3}(37.97 \%)($ Table 5$)$.

\section{Ear head length}

Analysis of variances revealed significant difference between crosses and $\mathrm{P}$ Vs $\mathrm{C}$ for all the four environments and over the environments. Heterosis ranged from -16.47 $\left(\mathrm{L}_{3} \times \mathrm{T}_{1}\right)$ to $25.00\left(\mathrm{~L}_{5} \times \mathrm{T}_{1}\right)$ in $\mathrm{E} 1,-13.34\left(\mathrm{~L}_{6}\right.$ $\left.\mathrm{x} \mathrm{T}_{2}\right)$ to $21.92\left(\mathrm{~L}_{7} \times \mathrm{T}_{1}\right)$ in $\mathrm{E}_{2},-21.43\left(\mathrm{~L}_{10} \mathrm{x}\right.$ $\left.\mathrm{T}_{2}\right)$ to $27.61\left(\mathrm{~L}_{7} \times \mathrm{T}_{3}\right)$ in $\mathrm{E}_{3}, 13.92\left(\mathrm{~L}_{5} \times \mathrm{T}_{1}\right)$ to $23.64\left(\mathrm{~L}_{4} \times \mathrm{T}_{1}\right)$ in $\mathrm{E}_{4}$ and $-5.77\left(\mathrm{~L}_{9} \times \mathrm{T}_{2}\right)$ to $16.72\left(\mathrm{~L}_{5} \times \mathrm{T}_{1}\right)$ per cent in pool. The negative heterosis was significant for 1, 2, 5 and 3 crosses in $E_{1}, E_{2}, E_{3}$ and pool, respectively and positive heterosis was significant for $5,4,8,4$ and 9 crosses in $E_{1}, E_{2}, E_{3}, E_{4}$ and pool, respectively.

Heterobeltiosis was significant for 2, 2, 2, 3 and 4 crosses in $E_{1}, E_{2}, E_{3}, E_{4}$ and pool, respectively. The highest magnitude of heterobeltiosis was $25.00\left(\mathrm{~L}_{5} \times \mathrm{T}_{1}\right), 20.27\left(\mathrm{~L}_{7}\right.$ $\left.\mathrm{x} \mathrm{T}_{1}\right), 19.54\left(\mathrm{~L}_{7} \mathrm{x} \mathrm{T}_{3}\right)$ and $14.10\left(\mathrm{~L}_{7} \times \mathrm{T}_{1}\right)$ per cent in $\mathrm{E}_{1}, \mathrm{E}_{2}, \mathrm{E}_{3}, \mathrm{E}_{4}$ and pool, respectively. Cross $\mathrm{L}_{7} \times \mathrm{T}_{1}$ exhibited significant and positive heterobeltiosis in $\mathrm{E}_{2}, \mathrm{E}_{4}$ and pool. Economic heterosis was not significant in any cross in any environment (Table 6).

\section{Number of primaries per plant}

Analysis of variances revealed significant difference between crosses in all the four environments. The P Vs C were significant in
$E_{2}, E_{3}$ and $E_{4}$ Magnitude of heterosis ranged from $-40.95\left(\mathrm{~L}_{10} \times \mathrm{T}_{2}\right)$ to 59.06 per cent $\left(\mathrm{L}_{6} \mathrm{X}\right.$ $\left.\mathrm{T}_{3}\right)$ in $\mathrm{E}_{1},-37.31\left(\mathrm{~L}_{6} \times \mathrm{T}_{2}\right)$ to 75.65 per cent $\left(\mathrm{L}_{4} \times \mathrm{T}_{2}\right)$ in $\mathrm{E}_{2},-30.59\left(\mathrm{~L}_{3} \times \mathrm{T}_{1}\right)$ to 78.42 per cent $\left(\mathrm{L}_{5} \times \mathrm{T}_{1}\right)$ in $\mathrm{E}_{3}$ and $-24.65\left(\mathrm{~L}_{5} \times \mathrm{T}_{3}\right)$ to 127.47 per cent $\left(\mathrm{L}_{5} \times \mathrm{T}_{2}\right)$ in $\mathrm{E}_{4}$. The negative heterosis was significant for 7, 4 and 4 crosses in $E_{2}, E_{3}$ and $E_{4}$, respectively and positive heterosis was significant for 9,6 and 8 crosses in $\mathrm{E}_{2}, \mathrm{E}_{3}$ and $\mathrm{E}_{4}$, respectively.

The heterobeltiosis in positive direction was significant for 3, 3, 1 and 5 crosses in $E_{1} E_{2}, E_{3}$ and $\mathrm{E}_{4}$, respectively. The highest magnitude of heterobeltiosis was $48.53\left(\mathrm{~L}_{6} \times \mathrm{T}_{3}\right), 52.32$ $\left(\mathrm{L}_{10} \times \mathrm{T}_{2}\right), 25.00\left(\mathrm{~L}_{5} \times \mathrm{T}_{1}\right)$ and 84.03 per cent $\left(\mathrm{L}_{5} \times \mathrm{T}_{2}\right)$ in $\mathrm{E}_{1}, \mathrm{E}_{2}, \mathrm{E}_{3}$ and $\mathrm{E}_{4}$ respectively. Crosses $L_{5} \times T_{1}$ in $E_{3}$ and $E_{4}$ and $L_{5} \times T_{2}$ and $\mathrm{L}_{10} \times \mathrm{T}_{2}$ in $\mathrm{E}_{2}$ and $\mathrm{E}_{4}$ exhibited significant and positive heterobeltioss in more than one environment. Economic heterosis was not significant in any cross in any environment (Table 7).

\section{Number of seeds per primary}

Analysis of variances revealed significant difference between crosses and $\mathrm{P}$ Vs $\mathrm{C}$ in all the four environments. The heterosis ranged from $-56.15\left(\mathrm{~L}_{1} \times \mathrm{T}_{2}\right)$ to 155.27 per cent $\left(\mathrm{L}_{8} \mathrm{X}\right.$ $\left.\mathrm{T}_{1}\right)$ in $\mathrm{E}_{1},-54.69\left(\mathrm{~L}_{2} \times \mathrm{T}_{1}\right)$ to 80.42 per cent $\left(\mathrm{L}_{7} \times \mathrm{T}_{2}\right)$ in $\mathrm{E}_{2},-53.37\left(\mathrm{~L}_{10} \times \mathrm{T}_{3}\right)$ to 142.75 per cent $\left(\mathrm{L} 4 \times \mathrm{T}_{2}\right)$ in $\mathrm{E}_{3}$ and $-47.29\left(\mathrm{~L}_{9} \mathrm{x} \mathrm{T}_{3}\right)$ to 44.72 per cent $\left(\mathrm{L}_{2} \times \mathrm{T}_{3}\right)$ in $\mathrm{E}_{4}$. The negative heterosis was significant for 12, 8, 9 and 13 crosses in $E_{1}, E_{2}, E_{3}$ and $E_{4}$, respectively and positive heterosis was significant for 10,10 , 11 and 4 crosses in $E_{1}, E_{2}, E_{3}$ and $E_{4}$, respectively

The heterobeltiosis in positive direction was significant for 7, 3 and 6 crosses in $E_{1}, E_{2}$ and $E_{3}$, respectively. The highest magnitude of heterobeltiosis was $137.04\left(\mathrm{~L}_{8} \times \mathrm{T}_{1}\right), 59.35$ $\left(\mathrm{L} 7 \times \mathrm{T}_{2}\right)$ and $101.81\left(\mathrm{~L}_{4} \times \mathrm{T}_{2}\right)$ percent in $\mathrm{E}_{1}$, $\mathrm{E}_{2}$ and $\mathrm{E}_{3}$, respectively. Crosses $\mathrm{L}_{4} \times \mathrm{T}_{2}$ and $\mathrm{L}_{4}$ 
$x T_{3}$ in $E_{1}$ and $E_{3}$ and $L_{6} \times T_{2}$ and $L_{7} \times T_{2}$ in $E_{2}$ and $E_{3}$ exhibited significant and positive heterobeltioss in more than than one environment.

The economic heterosis was significant for $\mathrm{L}_{8}$ $\mathrm{x} \mathrm{T}_{1}(11.72 \%), \mathrm{L}_{4} \times \mathrm{T}_{2}(27.43 \%)$ and $\mathrm{L}_{7} \times \mathrm{T}_{3}$ $(11.47 \%)$ in $\mathrm{E}_{1}, \mathrm{~L}_{7} \times \mathrm{T}_{2}(39.18 \%)$ in $\mathrm{E}_{2}$ and $\mathrm{L}_{2} \times \mathrm{T}_{1}(19.68 \%), \mathrm{L}_{4} \times \mathrm{T}_{2}(34.54 \%), \mathrm{L}_{2} \times \mathrm{T}_{3}$ $(15.66 \%), \mathrm{L}_{4} \times \mathrm{T}_{3}(36.95 \%)$ in $\mathrm{E}_{3}$ (Table 8).

\section{Seed index}

Analysis of variances revealed significant difference between crosses and P Vs C in all the four environments. The magnitude of heterosis ranged from $25.92\left(\mathrm{~L}_{6} \times \mathrm{T}_{1}\right)$ to 15.45 per cent $\left(\mathrm{L}_{3} \times \mathrm{T}_{2}\right)$ in $\mathrm{E}_{1}, 30.53\left(\mathrm{~L}_{2} \times \mathrm{T}_{2}\right)$ to -21.55 per cent $\left(\mathrm{L}_{3} \times \mathrm{T}_{1}\right)$ in $\mathrm{E}_{2}, 38.94\left(\mathrm{~L}_{4} \mathrm{X}\right.$ $\left.\mathrm{T}_{3}\right)$ to -15.92 per cent $\left(\mathrm{L}_{5} \times \mathrm{T}_{1}\right)$ in $\mathrm{E}_{3}$ and $38.00\left(\mathrm{~L}_{10} \times \mathrm{T} 2\right)$ to -13.12 per cent $\left(\mathrm{L}_{9} \times \mathrm{T}_{1}\right)$ in $\mathrm{E}_{4}$. The positive heterosis was significant for 12, 12, 16 and 19 crosses and negative for $8,12,2$ and 8 crosses in $\mathrm{E}_{1} \mathrm{E}_{2}, \mathrm{E}_{3}$ and $\mathrm{E}_{4}$, respectively.

Heterobeltiosis in positive direction was significant for $6,6,11$ and 16 crosses in $\mathrm{E}_{1}$, $\mathrm{E}_{2}, \mathrm{E}_{3}$ and $\mathrm{E}_{4}$ respectively. The maximum value of heterobeltiosis was 22.58 (L6 x T1), $24.72\left(\mathrm{~L}_{5} \times \mathrm{T}_{3}\right), 38.87\left(\mathrm{~L}_{4} \times \mathrm{T}_{3}\right)$ and 34.39 per cent $\left(L_{2} \times T_{3}\right)$ in $E_{1}, E_{2}, E_{3}$ and $E_{4}$ respectively. Crosses $\mathrm{L}_{3} \times \mathrm{T}_{1}$ and $\mathrm{L}_{4} \times \mathrm{T}_{2}$ exhibited significant and positive heterobeltiosis in $E_{3}$ and $E_{4}$ and $L_{2} \times T_{2}$ in $E_{1}$ and $\mathrm{E}_{2}$.

The economic heterosis was significant for 3 crosses viz., $\mathrm{L}_{3} \times \mathrm{T}_{1}$ (7.69), $\mathrm{L}_{3} \times \mathrm{T}_{2}$ (5.86) and $\mathrm{L}_{5} \mathrm{X} \mathrm{T}_{3}$ (4.30) only in $\mathrm{E}_{4}$ (Table 9).

\section{Harvest index}

Analysis of variances revealed significant difference between crosses in $\mathrm{E}_{3}$ and $\mathrm{E}_{4}$ only and $\mathrm{P}$ Vs $\mathrm{C}$ was non-significant in all the four environments. The heterosis for harvest index ranged from $46.10\left(\mathrm{~L}_{10} \times \mathrm{T}_{1}\right)$ to $-53.75 \mathrm{per}$ cent $\left(\mathrm{L}_{3} \times \mathrm{T}_{3}\right)$ in $\mathrm{E}_{3}$ and $26.54\left(\mathrm{~L}_{7} \times \mathrm{T}_{3}\right)$ to 14.24 per cent $\left(\mathrm{L}_{1} \times \mathrm{T}_{2}\right)$ in $\mathrm{E}_{4}$. Positive heterosis was significant for 8 crosses in $\mathrm{E}_{3}$ and 6 crosses in $\mathrm{E}_{4}$ where as negative heterosis was significant for 3 crosses in $\mathrm{E}_{3}$ and 5 crosses in $\mathrm{E}_{4}$.

Heterobeltiosis was significant for cross $\mathrm{L}_{10} \mathrm{x}$ $\mathrm{T}_{1}(36.80 \%)$ in $\mathrm{E}_{3}$ and $\mathrm{L}_{2} \times \mathrm{T}_{1}(10.33 \%)$ crosses in $\mathrm{E}_{4}$. Economic heterosis was not significant in any cross in any environment (Table 10).

\section{Grain yield}

Difference between crosses and P Vs C were significant in all the four environments. The magnitude of heterosis ranged from $98.78\left(\mathrm{~L}_{2}\right.$ $\left.\mathrm{x} \mathrm{T}_{2}\right)$ to -56.19 per cent $\left(\mathrm{L}_{5} \mathrm{x} \mathrm{T}_{2}\right)$ in $\mathrm{E}_{1}$, $251.38\left(\mathrm{~L}_{1} \times \mathrm{T}_{3}\right)$ to -57.79 per cent $\left(\mathrm{L}_{6} \times \mathrm{T}_{1}\right)$ in $\mathrm{E}_{2}, 75.59\left(\mathrm{~L}_{2} \times \mathrm{T}_{1}\right)$ to -38.86 per cent $\left(\mathrm{L}_{3} \mathrm{X}\right.$ $\left.\mathrm{T}_{2}\right)$ in $\mathrm{E}_{3}$ and $143.14\left(\mathrm{~L}_{6} \times \mathrm{T}_{1}\right)$ to -56.08 per cent $\left(\mathrm{L}_{6} \times \mathrm{T}_{3}\right)$ in $\mathrm{E}_{4}$. The positive heterosis was significant for 15, 10, 19 and 9 crosses and negative for 7, 11, 6 and 14 crosses in $E_{1}$ $\mathrm{E}_{2}, \mathrm{E}_{3}$ and $\mathrm{E}_{4}$, respectively.

Heterobeltiosis in positive direction was significant for 7, 8, 14 and 7 crosses in $E_{1}, E_{2}$, $\mathrm{E}_{3}$ and $\mathrm{E}_{4}$ respectively. The maximum value of heterobeltiosis was $73.40\left(\mathrm{~L}_{2} \times \mathrm{T}_{2}\right), 158.54$ $\left(\mathrm{L}_{1} \times \mathrm{T}_{3}\right), 73.15\left(\mathrm{~L}_{2} \times \mathrm{T}_{1}\right)$ and 111.36 per cent $\left(\mathrm{L}_{6} \times \mathrm{T}_{1}\right)$ in $\mathrm{E}_{1}, \mathrm{E}_{2}, \mathrm{E}_{3}$ and $\mathrm{E}_{4}$, respectively. Crosses exhibited significant and positive heterobeltiosis in more than one environment were $\mathrm{L}_{6} \times \mathrm{T}_{1}, \mathrm{~L}_{7} \times \mathrm{T}_{1}$ and $\mathrm{L}_{9} \times \mathrm{T}_{2}$ in $\mathrm{E}_{3}$ and $\mathrm{E}_{4}$, $\mathrm{L}_{5} \times \mathrm{T}_{2}$ in $\mathrm{E}_{1}, \mathrm{E}_{3}$ and $\mathrm{E}_{4}$ and $\mathrm{L}_{2} \times \mathrm{T}_{2}$ in $\mathrm{E}_{1}$ and $\mathrm{E}_{4}$.

The economic heterosis was significant for 3 crosses viz., $\mathrm{L}_{1} \times \mathrm{T}_{3}(56.65 \%), \mathrm{L}_{2} \times \mathrm{T}_{3}(15.27$ $\%)$ and $\mathrm{L}_{6} \times \mathrm{T}_{3}(20.20 \%)$ in $\mathrm{E}_{2}$ only (Table 11). 


\section{Protein content in grain}

Difference between crosses and P Vs C were significant in all the four environments. The magnitude of heterosis ranged from $12.87\left(\mathrm{~L}_{7}\right.$ $\left.\mathrm{x} \mathrm{T}_{1}\right)$ to -19.00 per cent $\left(\mathrm{L}_{2} \times \mathrm{T}_{2}\right)$ in $\mathrm{E}_{1}, 18.43$ $\left(\mathrm{L}_{10} \times \mathrm{T}_{1}\right)$ to -33.31 per cent $\left(\mathrm{L}_{5} \times \mathrm{T}_{2}\right)$ in $\mathrm{E}_{2}$, $17.69\left(\mathrm{~L}_{10} \times \mathrm{T}_{2}\right)$ to -25.72 per cent $\left(\mathrm{L}_{8} \times \mathrm{T}_{2}\right)$ in $\mathrm{E}_{3}$ and $13.64\left(\mathrm{~L}_{3} \times \mathrm{T} 1\right)$ to -34.55 per cent $\left(\mathrm{L}_{1}\right.$ $\mathrm{x} \mathrm{T}_{3}$ ) in $\mathrm{E}_{4}$. The positive heterosis was significant for $4,5,5$ and 3 crosses and negative for $18,25,20$ and 27 crosses in $E_{1}$ $\mathrm{E}_{2}, \mathrm{E}_{3}$ and $\mathrm{E}_{4}$, respectively.

Heterobeltiosis in positive direction was significant for $\mathrm{L}_{7} \times \mathrm{T}_{1}(5.30 \%), \mathrm{L}_{3} \times \mathrm{T}_{1}(6.31$ $\%), \mathrm{L}_{1} \times \mathrm{T}_{2}(10.94 \%)$ and $\mathrm{L}_{3} \times \mathrm{T}_{1}(10.40 \%)$ in $\mathrm{E}_{1}, \mathrm{E}_{2}, \mathrm{E}_{3}$ and $\mathrm{E}_{4}$, respectively.

The economic heterosis was significant for $\mathrm{L}_{1}$ $\mathrm{x} \mathrm{T}_{2}(9.49 \%)$ cross in $\mathrm{E}_{3}$ only (Table 12 ).

\section{Protein content in fodder}

Difference between crosses and P Vs C were significant in all the four environments. The heterosis ranged from $28.79\left(\mathrm{~L}_{7} \times \mathrm{T}_{3}\right)$ to 27.59 per cent $\left(\mathrm{L}_{3} \times \mathrm{T}_{3}\right)$ in $\mathrm{E}_{1}, 30.93\left(\mathrm{~L}_{7} \times \mathrm{T}_{3}\right)$ to -37.27 per cent $\left(\mathrm{L}_{6} \times \mathrm{T}_{1}\right)$ in $\mathrm{E}_{2}, 31.61\left(\mathrm{~L}_{7} \mathrm{X}\right.$ $\left.\mathrm{T}_{3}\right)$ to -33.33 per cent $\left(\mathrm{L}_{6} \times \mathrm{T}_{3}\right)$ in $\mathrm{E}_{3}$ and $31.55\left(\mathrm{~L}_{7} \times \mathrm{T} 1\right)$ to -35.73 per cent $\left(\mathrm{L}_{6} \times \mathrm{T}_{1}\right)$ in $\mathrm{E}_{4}$. The negative heterosis was significant for $14,15,14$ and 15 crosses and positive for 10 , 12,13 and 13 crosses in $E_{1} E_{2}, E_{3}$ and $E_{4}$, respectively.

Heterobeltiosis in positive direction was significant for 9, 8, 8 and 10 crosses in $\mathrm{E}_{1}, \mathrm{E}_{2}$, $\mathrm{E}_{3}$ and $\mathrm{E}_{4}$, respectively. The maximum value of heterobeltiosis was $21.61\left(\mathrm{~L}_{9} \times \mathrm{T}_{2}\right), 15.13$ $\left(\mathrm{L}_{7} \times \mathrm{T}_{2}\right), 16.23\left(\mathrm{~L}_{7} \times \mathrm{T}_{2}\right)$ and 16.52 per cent $\left(L_{7} \times T_{2}\right)$ in $E_{1}, E_{2}, E_{3}$ and $E_{4}$, respectively. Crosses exhibited significant and positive heterobeltiosis in more than one environments were $\mathrm{L}_{1} \times \mathrm{T}_{1}, \mathrm{~L}_{4} \times \mathrm{T}_{2}, \mathrm{~L}_{3} \times \mathrm{T}_{3}$ and $\mathrm{L}_{7} \times \mathrm{T}_{2}$ in $\mathrm{E}_{2}, \mathrm{E}_{3} \mathrm{E}_{4}$ and $\mathrm{L}_{7} \times \mathrm{T}_{1}, \mathrm{~L} 8 \times \mathrm{T}_{1}, \mathrm{~L}_{2} \times \mathrm{T}_{3}$ and $\mathrm{L}_{7} \mathrm{x}$ $T_{3}$ in $E_{1}, E_{2}, E_{3}$ and $E_{4}$.
The economic heterosis was significant for 2 crosses viz., $\mathrm{L}_{2} \times \mathrm{T}_{3}(8.34 \%)$ and $\mathrm{L}_{4} \times \mathrm{T}_{3}(6.66$ $\%)$ in $\mathrm{E}_{1}$ (Table 13).

The difference between mean of parents and mean of $F_{1}$ 's was significant for all the characters in all the environments except harvest index in all the environments and green fodder yield and number of primaries per plant in $E_{1}$. This suggested significant deviation of $F_{1}$ means from parental means. Mean of the $F_{1}$ 's was significantly decreased for days to $50 \%$ flowering, days to maturity, protein content in grain and protein content in fodder in all the four environments whereas, for number of primaries per plant in $E_{1}$, green fodder yield in $\mathrm{E}_{3}$ and number of seeds per primary in $\mathrm{E}_{4}$. For plant height, grain yield, dry fodder yield, ear head length, number of primaries per plant, number of seeds per primary, seed index the $F_{1}$ mean was higher than parental mean except for green fodder yield in $\mathrm{E}_{3}$, number of primaries per plant in $\mathrm{E}_{1}$ and number of seeds per primary in $\mathrm{E}_{4}$. Increase in $F_{1}$ mean was also observed for protein content in fodder in $\mathrm{E}_{1}$. This indicates presence of average heterosis for these characters in above environments. Such average heterosis was also observed by Khapre et al., (2000), Umakanth et al., (2006), Kulkarni et al., (2007), Salini et al., (2008), Murty et al., (2010), Thakare et al., (2011) and Hariprasanna et al., (2012) for different characters. Differences between crosses were significant in all the four environments except harvest index in $\mathrm{E}_{1}$ and $\mathrm{E}_{2}$. In the present investigation, significant heterosis over mid parent was observed for all the characters in most of the crosses. For grain yield the magnitude of heterosis ranged from $-56.19\left(\mathrm{~L}_{5} \times \mathrm{T}_{2}\right)$ to $98.78\left(\mathrm{~L}_{2} \times \mathrm{T}_{2}\right)$ per cent in $\mathrm{E}_{1}$, from $-57.79\left(\mathrm{~L}_{6} \times \mathrm{T}_{1}\right)$ to $251.38\left(\mathrm{~L}_{1}\right.$ $\left.\mathrm{x} \mathrm{T}_{3}\right)$ per cent in $\mathrm{E}_{2}$, from $-38.86\left(\mathrm{~L}_{3} \times \mathrm{T}_{2}\right)$ to $75.59\left(\mathrm{~L}_{2} \times \mathrm{T}_{1}\right)$ per cent in $\mathrm{E}_{3}$ and from-56.08 $\left(\mathrm{L}_{6} \times \mathrm{T}_{3}\right)$ to $143.14\left(\mathrm{~L}_{6} \times \mathrm{T}_{1}\right)$ per cent in $\mathrm{E}_{4}$. 
Int.J.Curr.Microbiol.App.Sci (2017) 6(5): 990-1014

Table.1 Heterosis for days to $50 \%$ flowering

\begin{tabular}{|c|c|c|c|c|c|c|c|c|c|c|c|c|c|}
\hline \multirow[t]{2}{*}{ S. No. } & \multirow{2}{*}{ Crosses } & \multicolumn{4}{|c|}{ Heterosis } & \multicolumn{4}{|c|}{ Heterobeltiosis } & \multicolumn{4}{|c|}{ Economic Heterosis } \\
\hline & & E1 & E2 & E3 & $\mathbf{E 4}$ & E1 & E2 & E3 & E4 & E1 & E2 & E3 & $\mathbf{E 4}$ \\
\hline 1. & L1 $\times$ T1 & 0.23 & $-7.69 * *$ & -3.77 & -5.01 & - & $-6.85^{*}$ & -3.13 & -1.49 & - & - & -0.91 & - \\
\hline 2. & L2 $\times$ T1 & 3.20 & 3.63 & $-9.46^{* *}$ & -1.77 & - & - & $-8.64 * *$ & - & - & - & $-8.22 * *$ & - \\
\hline 3. & L3 $x$ T1 & 5.26 & 1.69 & -1.33 & $8.25^{*}$ & - & - & -0.89 & - & - & - & - & - \\
\hline 4. & L4 $\times \mathrm{T} 1$ & -6.18 & $-11.06 * *$ & $-11.96 * *$ & -1.01 & -5.53 & $-10.05 * *$ & $-10.96 * *$ & - & - & - & $-10.96 * *$ & - \\
\hline 5. & L5 $\times$ T1 & -1.42 & $-8.31 * *$ & $-8.44 * *$ & -4.28 & - & -4.46 & $-8.04 * *$ & -2.56 & - & -0.52 & $-5.94 *$ & - \\
\hline 6. & L6 $\times$ T1 & -0.95 & $-11.31 * *$ & $-6.90 * *$ & -5.36 & - & $-10.50 * *$ & $-6.70 *$ & - & - & - & -4.57 & - \\
\hline 7. & L7 $\times$ T1 & 4.74 & $-11.66 * *$ & $-11.86 * *$ & $-8.76^{* *}$ & - & $-10.05^{* *}$ & $-11.66 * *$ & -1.98 & - & - & $-10.05^{* *}$ & - \\
\hline 8. & L8 $\times$ T1 & $-19.73 * *$ & -2.52 & $-15.96 * *$ & $-13.62 * *$ & $-18.43 * *$ & -2.29 & $-15.38 * *$ & $-8.91 *$ & $-11.94 *$ & - & $-14.61 * *$ & -1.08 \\
\hline 9. & L9 $\times$ T1 & -3.37 & $-10.36 * *$ & $-9.21 * *$ & 0.47 & -0.92 & $-9.13^{* *}$ & $-7.59 * *$ & - & - & - & $-5.48^{*}$ & - \\
\hline 10. & $\mathrm{~L} 10 \times \mathrm{T} 1$ & -7.09 & -2.74 & -0.89 & -1.65 & -6.45 & -2.74 & -0.89 & - & - & - & - & - \\
\hline 11. & L1 $\times$ T2 & -2.42 & $-8.92 * *$ & 0.00 & $10.29^{* *}$ & 0.00 & $-7.01 *$ & - & - & - & - & - & - \\
\hline 12. & $\mathrm{~L} 2 \times \mathrm{T} 2$ & -4.85 & 0.98 & -3.40 & $13.54^{* *}$ & -2.26 & - & -3.18 & - & - & - & -2.74 & - \\
\hline 13. & L3 $\times$ T2 & -5.99 & -3.90 & -2.01 & 3.98 & - & - & -0.90 & - & - & - & 0.00 & - \\
\hline 14. & $\mathrm{~L} 4 \times \mathrm{T} 2$ & $-26.71 * *$ & $-9.13 * *$ & -3.64 & $9.09^{*}$ & $-24.55^{* *}$ & $-7.01 *$ & -3.20 & - & $-17.41 * *$ & - & -3.20 & - \\
\hline 15. & L5 $\times$ T2 & -5.91 & -4.81 & $-11.41 * *$ & $16.06^{* *}$ & 0.00 & -1.98 & $-10.41 * *$ & - & - & - & $-9.59 * *$ & - \\
\hline 16. & L6 $\times$ T2 & -8.68 & $-12.59 * *$ & $-15.70 * *$ & 5.26 & -2.44 & $-10.75^{* *}$ & $-14.93 * *$ & - & -0.50 & -1.55 & $-14.16^{* * *}$ & - \\
\hline 17. & L7 $\times$ T2 & $-14.60 * *$ & $-7.94 * *$ & -3.15 & -1.65 & $-13.27 *$ & -5.14 & -2.71 & - & -2.49 & - & -1.83 & - \\
\hline 18. & L8 $\times$ T2 & $-20.35^{* *}$ & $-17.59 * *$ & $-14.93^{* *}$ & $-7.95^{*}$ & $-18.75^{* *}$ & $-16.82 * *$ & $-14.93 * *$ & 0.00 & -9.45 & $-8.25^{*}$ & $-14.16^{* *}$ & - \\
\hline 19. & L9 $\times$ T2 & -6.29 & $5.69^{*}$ & -1.55 & 3.61 & -5.26 & - & - & - & - & - & - & - \\
\hline 20. & $\mathrm{~L} 10 \times \mathrm{T} 2$ & -4.19 & $-6.24 *$ & $-8.76^{* *}$ & -5.80 & -1.36 & -5.14 & $-8.14 * *$ & - & - & - & $-7.31 * *$ & - \\
\hline 21. & L1 1 T3 & 2.02 & 3.89 & 0.44 & $-7.11 *$ & - & - & - & -4.39 & - & - & - & - \\
\hline 22. & L2 $\times$ T3 & -0.90 & $5.88^{*}$ & -0.22 & -1.01 & -0.45 & - & - & - & - & - & - & - \\
\hline 23. & L3 $\times$ T3 & 4.25 & $12.20 * *$ & 2.00 & $10.49^{* *}$ & - & - & - & - & - & - & - & - \\
\hline 24. & L4 $\times$ T3 & -5.19 & $-8.22 * *$ & $-11.26 * *$ & -2.76 & -4.55 & $-6.07 *$ & $-10.05 * *$ & 0.00 & - & - & $-10.05 * *$ & - \\
\hline 25. & L5 $\times$ T3 & 6.98 & -0.48 & 0.67 & -3.50 & - & - & - & -1.03 & - & - & - & - \\
\hline 26. & L6 $x$ T3 & 3.74 & -2.06 & $-8.44 * *$ & -3.24 & - & 0.00 & $-8.44 * *$ & - & - & - & $-5.94 *$ & - \\
\hline 27. & L7 $\times$ T3 & -0.22 & $-8.84 * *$ & $-11.16^{* *}$ & $-13.04 * *$ & - & $-6.07 *$ & $-10.76^{* *}$ & -7.32 & - & - & $-9.13 * *$ & - \\
\hline 28. & L8 $x$ T3 & -7.38 & $-10.19 * *$ & $-14.80 * *$ & $-17.95 * *$ & -7.17 & $-9.35 * *$ & $-14.03^{* *}$ & $-14.15^{* *}$ & - & 0.00 & $-13.24 * *$ & -5.38 \\
\hline 29. & L9 $\times$ T3 & -2.44 & -0.23 & -3.28 & 4.43 & -1.35 & - & -1.78 & - & - & - & - & - \\
\hline 30. & L10 x T3 & 1.58 & 4.85 & -2.00 & -1.40 & - & - & -1.79 & - & - & - & - & - \\
\hline
\end{tabular}

** Significant at 5 and 1 per cent, respectively. 
Int.J.Curr.Microbiol.App.Sci (2017) 6(5): 990-1014

Table. 1 continued

\begin{tabular}{|c|c|c|c|c|c|c|c|c|c|c|c|c|c|c|c|}
\hline \multirow{2}{*}{$\begin{array}{l}\text { S. } \\
\text { No. }\end{array}$} & \multirow{2}{*}{\multicolumn{3}{|c|}{ Crosses }} & \multicolumn{4}{|l|}{ Heterosis } & \multicolumn{4}{|c|}{ Heterobeltiosis } & \multicolumn{4}{|c|}{ Economic Heterosis } \\
\hline & & & & E1 & E2 & E3 & E4 & E1 & E2 & E3 & E4 & E1 & E2 & E3 & E4 \\
\hline 1. & L1 & $x T$ & T1 & 0.23 & $-7.69 * *$ & -3.77 & -5.01 & - & $-6.85 *$ & -3.13 & -1.49 & - & - & -0.91 & - \\
\hline 2. & L2 & $x T$ & T1 & 3.20 & 3.63 & $-9.46 * *$ & -1.77 & - & - & $-8.64 * *$ & - & - & - & $-8.22 * *$ & - \\
\hline 3. & L3 & $x T$ & T1 & 5.26 & 1.69 & -1.33 & $8.25^{*}$ & - & - & -0.89 & - & - & - & - & - \\
\hline 4. & L4 & $x T$ & T1 & -6.18 & $-11.06 * *$ & $-11.96 * *$ & -1.01 & -5.53 & $-10.05 * *$ & $-10.96 * *$ & - & - & - & $-10.96 * *$ & - \\
\hline 5. & L5 & $x T$ & T1 & -1.42 & $-8.31 * *$ & $-8.44 * *$ & -4.28 & - & -4.46 & $-8.04 * *$ & -2.56 & - & -0.52 & $-5.94 *$ & - \\
\hline 6 . & L6 & $x T$ & T1 & -0.95 & $-11.31 * *$ & $-6.90 * *$ & -5.36 & - & $-10.50 * *$ & $-6.7 \theta^{*}$ & - & - & - & -4.57 & - \\
\hline 7. & L7 & $x T$ & T1 & 4.74 & $-11.66 * *$ & $-11.86 * *$ & $-8.76 * *$ & - & $-10.05 * *$ & $-11.66 * *$ & -1.98 & - & - & $-10.05 * *$ & - \\
\hline 8. & L8 & $x T$ & T1 & $-19.73 * *$ & -2.52 & $-15.96 * *$ & $-13.62 * *$ & $-18.43 * *$ & -2.29 & $-15.38 * *$ & $-8.91 *$ & $-11.94 *$ & - & $-14.61 * *$ & -1.08 \\
\hline 9. & L9 & $x T$ & T1 & -3.37 & $-10.36 * *$ & $-9.21 * *$ & 0.47 & -0.92 & $-9.13 * *$ & $-7.59 * *$ & - & - & - & $-5.48 *$ & - \\
\hline 10. & L10 & $x T$ & T1 & -7.09 & -2.74 & -0.89 & -1.65 & -6.45 & -2.74 & -0.89 & - & - & - & - & - \\
\hline 11. & L1 & $x T$ & $\mathrm{~T} 2$ & -2.42 & $-8.92 * *$ & 0.00 & $10.29 * *$ & 0.00 & $-7.01 *$ & - & - & - & - & - & - \\
\hline 12. & L2 & $x T$ & $\mathrm{~T} 2$ & -4.85 & 0.98 & -3.40 & $13.54 * *$ & -2.26 & - & -3.18 & - & - & - & -2.74 & - \\
\hline 13. & L3 & $x T$ & $\mathrm{~T} 2$ & -5.99 & -3.90 & -2.01 & 3.98 & - & - & -0.90 & - & - & - & 0.00 & - \\
\hline 14. & L4 & $x T$ & $\mathrm{~T} 2$ & $-26.71 * *$ & $-9.13 * *$ & -3.64 & $9.09 *$ & $-24.55 * *$ & $-7.01 *$ & -3.20 & - & $-17.41 * *$ & - & -3.20 & - \\
\hline 15. & L5 & $x T$ & $\mathrm{~T} 2$ & -5.91 & -4.81 & $-11.41 * *$ & $16.06 * *$ & 0.00 & -1.98 & $-10.41 * *$ & - & - & - & $-9.59 * *$ & - \\
\hline 16. & L6 & $x T$ & $\mathrm{~T} 2$ & -8.68 & $-12.59 * *$ & $-15.70 * *$ & 5.26 & -2.44 & $-10.75^{* *}$ & $-14.93 * *$ & - & -0.50 & -1.55 & $-14.16 * *$ & - \\
\hline 17. & L7 & $x T$ & $\mathrm{~T} 2$ & $-14.60^{* *}$ & $-7.94 * *$ & -3.15 & -1.65 & $-13.27^{*}$ & -5.14 & -2.71 & - & -2.49 & - & -1.83 & - \\
\hline 18. & L8 & $x T$ & T2 & $-20.35 * *$ & $-17.59 * *$ & $-14.93 * *$ & $-7.95 *$ & $-18.75 * *$ & $-16.82 * *$ & $-14.93 * *$ & 0.00 & -9.45 & $-8.25 *$ & $-14.16 * *$ & - \\
\hline 19. & L9 & $x T$ & $\mathrm{~T} 2$ & -6.29 & $5.69 *$ & -1.55 & 3.61 & -5.26 & - & - & - & - & - & - & - \\
\hline 20 . & L10 & $x T$ & T2 & -4.19 & $-6.24 *$ & $-8.76 * *$ & -5.80 & -1.36 & -5.14 & $-8.14 * *$ & - & - & - & $-7.31 * *$ & - \\
\hline 21. & L1 & $x T$ & T3 & 2.02 & 3.89 & 0.44 & $-7.11 *$ & - & - & - & -4.39 & - & - & - & - \\
\hline 22 . & L2 & $x T$ & T3 & -0.90 & $5.88^{*}$ & -0.22 & -1.01 & -0.45 & - & - & - & - & - & - & - \\
\hline 23. & L3 & $x 1$ & T3 & 4.25 & $12.20 * *$ & 2.00 & $10.49 * *$ & - & - & - & - & - & - & - & - \\
\hline 24 . & L4 & $x 1$ & T3 & -5.19 & $-8.22 * *$ & $-11.26 * *$ & -2.76 & -4.55 & $-6.07 *$ & $-10.05^{* *}$ & 0.00 & - & - & $-10.05 * *$ & - \\
\hline 25 . & L5 & $x T$ & T3 & 6.98 & -0.48 & 0.67 & -3.50 & - & - & - & -1.03 & - & - & - & - \\
\hline 26. & L6 & $x T$ & T3 & 3.74 & -2.06 & $-8.44 * *$ & -3.24 & - & 0.00 & $-8.44 * *$ & - & - & - & $-5.94 *$ & - \\
\hline 27. & L7 & $\times 1$ & T3 & -0.22 & $-8.84 * *$ & $-11.16 * *$ & $-13.04 * *$ & - & $-6.07 *$ & $-10.76 * *$ & -7.32 & - & - & $-9.13 * *$ & - \\
\hline 28. & L8 & $\times 1$ & T3 & -7.38 & $-10.19 * *$ & $-14.80 * *$ & $-17.95 * *$ & -7.17 & $-9.35 * *$ & $-14.03 * *$ & $-14.15^{* *}$ & - & 0.00 & $-13.24 * *$ & -5.38 \\
\hline 29. & L9 & $x$ & T3 & -2.44 & -0.23 & -3.28 & 4.43 & -1.35 & - & -1.78 & - & - & - & - & - \\
\hline 30. & L10 & $\times 1$ & T3 & 1.58 & 4.85 & -2.00 & -1.40 & - & - & -1.79 & - & - & - & - & - \\
\hline
\end{tabular}

** Significant at 5 and 1 per cent, respectively. 
Int.J.Curr.Microbiol.App.Sci (2017) 6(5): 990-1014

Table. 2 Heterosis for days to maturity

\begin{tabular}{|c|c|c|c|c|c|c|c|c|c|c|c|c|c|}
\hline \multirow[t]{2}{*}{ S.No. } & \multirow[t]{2}{*}{ Crosses } & \multicolumn{4}{|c|}{ Heterosis } & \multicolumn{4}{|c|}{ Heterobeltiosis } & \multicolumn{4}{|c|}{ Economic Heterosis } \\
\hline & & E1 & E2 & E3 & E4 & E1 & E2 & $\mathbf{E 3}$ & $\mathbf{E 4}$ & E1 & E2 & E3 & $\mathbf{E 4}$ \\
\hline 1. & $\mathrm{~L} 1 \times \mathrm{T} 1$ & -1.78 & $-2.43 * *$ & $-1.79 *$ & -0.96 & -0.66 & -0.66 & -0.66 & - & - & - & - & - \\
\hline 2. & $\mathrm{~L} 2 \times \mathrm{T} 1$ & $-3.31 * *$ & $-3.95 * *$ & $-2.65^{* *}$ & $-3.44 * *$ & 0.00 & -0.68 & 0.00 & 0.00 & - & - & - & - \\
\hline 3. & L3 $x$ T1 & $5.41^{* *}$ & $5.53 * *$ & $7.93^{* *}$ & $4.68^{* *}$ & - & - & - & - & - & - & - & - \\
\hline 4. & $\mathrm{~L} 4 \times \mathrm{T} 1$ & -0.00 & -0.00 & 1.14 & 0.00 & - & - & - & - & - & - & - & - \\
\hline 5. & L5 $\times \mathrm{T} 1$ & $-5.54 * *$ & $-4.55 * *$ & $-4.23 * *$ & $-5.31^{* *}$ & $-3.97 * *$ & $-2.65^{*}$ & $-3.29 * *$ & $-3.61 * *$ & - & - & - & - \\
\hline 6. & L6 $\times$ T1 & $-3.86^{* *}$ & $-4.32 * *$ & $-3.38 * *$ & $-4.14^{* *}$ & $-3.55^{* *}$ & $-3.86 * *$ & $-3.23 * *$ & $-3.53 * *$ & - & - & - & - \\
\hline 7. & L7 $x$ T1 & $-6.85^{* *}$ & $-5.92 * *$ & $-4.85^{* *}$ & $-6.96^{* *}$ & $-4.17 * *$ & $-3.82 * *$ & -1.94 & $-4.75^{* *}$ & - & - & - & - \\
\hline 8. & L8 $\times \mathrm{T} 1$ & $-10.25^{* *}$ & $-8.05 * *$ & $-8.10^{* *}$ & $-9.57 * *$ & $-7.37 * *$ & $-5.41 * *$ & $-4.84 * *$ & $-7.28 * *$ & - & - & - & - \\
\hline 9. & L9 $\times$ T1 & -1.56 & $-2.02 *$ & $-1.72 *$ & $-3.26^{* *}$ & - & - & - & -1.27 & - & - & - & - \\
\hline 10. & $\mathrm{~L} 10 \times \mathrm{T} 1$ & -1.71 & $-2.94 * *$ & -1.41 & $-2.02 *$ & - & 0.00 & - & -0.32 & - & - & - & - \\
\hline 11. & $\mathrm{~L} 1 \times \mathrm{T} 2$ & $5.47 * *$ & $5.80 * *$ & $5.14^{* *}$ & $4.62^{* *}$ & - & - & - & - & - & - & - & - \\
\hline 12. & L2 $\times$ T2 & $6.10^{* * *}$ & $5.39^{* *}$ & $6.06^{* *}$ & $5.21 * *$ & - & - & - & - & - & - & - & - \\
\hline 13. & L3 $\times$ T2 & $3.46^{* *}$ & $3.95^{* *}$ & $4.97 * *$ & $3.09 * *$ & - & - & - & - & - & - & - & - \\
\hline 14. & $\mathrm{~L} 4 \times \mathrm{T} 2$ & $2.64 *$ & $3.63 * *$ & $3.14 * *$ & $3.30^{* *}$ & - & - & - & - & - & - & - & - \\
\hline 15. & L5 $x$ T2 & $4.67 * *$ & $4.65^{* *}$ & $3.31 * *$ & $1.82 *$ & - & - & - & - & - & - & - & - \\
\hline 16. & L6 $\times$ T2 & 1.97 & 1.47 & $2.13^{*}$ & $1.96^{*}$ & - & - & - & - & - & - & - & - \\
\hline 17. & L7 $x$ T2 & $-5.73 * *$ & $-4.78 * *$ & $-4.93^{* *}$ & $-5.86^{* *}$ & -0.67 & -0.33 & -0.33 & -1.00 & - & - & - & - \\
\hline 18. & $\mathrm{~L} 8 \times \mathrm{T} 2$ & -1.27 & $-1.90^{*}$ & -1.58 & $-2.53^{* *}$ & - & - & - & - & - & - & - & - \\
\hline 19. & L9 $\times$ T2 & -0.96 & $-1.75^{*}$ & -0.79 & -1.11 & - & - & - & - & - & - & - & - \\
\hline 20. & $\mathrm{~L} 10 \times \mathrm{T} 2$ & $-11.92 * *$ & $-11.53^{* *}$ & $-10.33^{* *}$ & $-10.37 * *$ & $-7.05^{* *}$ & $-6.67 * *$ & $-6.00 * *$ & $-6.33^{* *}$ & -1.07 & -1.06 & -0.35 & -0.35 \\
\hline 21. & $\mathrm{~L} 1 \times \mathrm{T} 3$ & $-5.54 * *$ & $-4.59 * *$ & $-4.26 * *$ & $-4.25^{* *}$ & $-4.92 * *$ & $-3.96 * *$ & $-3.63 * *$ & $-4.25^{* *}$ & - & - & - & - \\
\hline 22. & $\mathrm{~L} 2 \times \mathrm{T} 3$ & -1.83 & $-2.50 * *$ & $-2.50^{* *}$ & $-2.50^{* *}$ & - & -0.34 & -0.34 & -0.68 & - & - & - & - \\
\hline 23. & L3 $x$ T3 & $4.58 * *$ & $4.07 * *$ & $4.07 * *$ & $5.10^{* *}$ & - & - & - & - & - & - & - & - \\
\hline 24. & $\mathrm{~L} 4 \times \mathrm{T} 3$ & $-6.65 * *$ & $-5.06 * *$ & $-4.58^{* *}$ & $-4.58^{* *}$ & $-6.49 * *$ & $-4.90 * *$ & $-4.26 * *$ & $-4.58^{* *}$ & - & - & - & - \\
\hline 25. & L5 $x$ T3 & $-2.78^{*}$ & $-2.79 * *$ & $-4.09 * *$ & $-3.44 * *$ & -1.66 & -1.99 & $-3.62 * *$ & $-3.28^{* *}$ & - & - & - & - \\
\hline 26. & L6 $x$ T3 & $-4.04 * *$ & $-5.18 * *$ & $-3.88^{* * *}$ & $-2.91 * *$ & $-3.88^{* *}$ & $-4.56 * *$ & $-3.26 * *$ & -1.96 & - & - & - & - \\
\hline 27. & L7 $\times$ T3 & $-6.42 * *$ & $-6.77 * *$ & $-6.92 * *$ & $-7.06^{* *}$ & $-3.24 *$ & $-3.58 * *$ & $-3.58 * *$ & $-3.27 * *$ & - & - & - & - \\
\hline 28. & L8 $\times$ T3 & $-2.96 * *$ & $-3.60 * *$ & $-3.60^{* *}$ & $-3.45^{* *}$ & - & - & - & - & - & - & - & - \\
\hline 29. & L9 $x$ T3 & -0.16 & -0.63 & -0.94 & -0.47 & - & - & - & - & - & - & - & - \\
\hline 30. & L10 x T3 & $-2.81 *$ & $-2.50 * *$ & -1.26 & -1.11 & - & - & - & - & - & - & - & - \\
\hline
\end{tabular}


Int.J.Curr.Microbiol.App.Sci (2017) 6(5): 990-1014

Table.3 Heterosis for plant height

\begin{tabular}{|c|c|c|c|c|c|c|c|c|c|c|c|c|c|c|c|c|}
\hline \multirow{2}{*}{$\begin{array}{l}\text { S. } \\
\text { No. }\end{array}$} & \multirow{2}{*}{ Crosses } & \multicolumn{5}{|c|}{ Heterosis } & \multicolumn{5}{|c|}{ Heterobeltiosis } & \multicolumn{5}{|c|}{ Economic Heterosis } \\
\hline & & E1 & E2 & E3 & E4 & Pool & E1 & E2 & E3 & E4 & pool & E1 & E2 & E3 & E4 & Pool \\
\hline 1. & L1 $\times$ T1 & -8.26 & 2.01 & 14.29 & $23.88^{*}$ & 6.97 & - & - & 0.00 & 14.12 & 4.94 & - & - & - & - & - \\
\hline 2. & $\mathrm{~L} 2 \times \mathrm{T} 1$ & 11.11 & $51.02 * *$ & $16.85^{*}$ & $18.67 *$ & $25.30 * *$ & - & $43.13^{* *} *$ & 13.04 & 9.07 & $16.77 * *$ & - & 2.49 & - & - & - \\
\hline 3. & L3 $\times$ T1 & $82.19 * *$ & 9.31 & $26.29 * *$ & 6.43 & $28.87 * *$ & $62.65^{* *}$ & 9.07 & $19.57^{*}$ & 5.81 & $27.26 * *$ & - & - & - & - & - \\
\hline 4. & L4 $\times$ T1 & $66.67 * *$ & 1.37 & 51.59 ** & $53.24 * *$ & $41.80 * *$ & $46.51^{* *}$ & - & $29.35^{* *}$ & $41.88 * *$ & $35.78 * *$ & - & - & - & - & - \\
\hline 5. & L5 $\times$ T1 & $61.16^{* * *}$ & $28.83 * *$ & $26.37 * *$ & $48.08 * *$ & $39.77 * *$ & $46.25 * *$ & $22.33 * *$ & $25.00 * *$ & $42.30 * *$ & $33.95 * *$ & - & - & - & - & - \\
\hline 6. & L6 $\times$ T1 & $49.55^{* *}$ & $31.28^{* *}$ & 9.69 & $23.84 * *$ & $27.75 * *$ & $28.35 * *$ & $29.35^{* *}$ & 7.52 & $21.87 *$ & $21.68 * *$ & - & - & - & - & - \\
\hline 7. & L7 $x$ T1 & 0.85 & 5.20 & 7.00 & $21.98^{*}$ & $8.32 *$ & - & - & - & 14.43 & - & - & - & - & - & - \\
\hline 8. & L8 $\times$ T1 & -7.50 & 9.01 & $17.05^{*}$ & 8.30 & 6.18 & - & 7.08 & 11.96 & - & - & - & - & - & - & - \\
\hline 9. & L9 $\times$ T1 & $26.06^{* * *}$ & 9.51 & -1.68 & $25.00 * *$ & $14.37 * *$ & 0.73 & 7.25 & - & $21.18^{*}$ & $8.59 *$ & - & - & - & - & - \\
\hline 10. & $\mathrm{~L} 10 \times \mathrm{T} 1$ & $89.83 * *$ & $26.35^{* *}$ & $42.05 * *$ & $23.10^{*}$ & $44.38 * *$ & $59.38 * *$ & $26.35^{* *}$ & $35.87 * *$ & $21.65^{*}$ & $40.16^{* *}$ & 2.00 & - & - & - & - \\
\hline 11. & $\mathrm{~L} 1 \times \mathrm{T} 2$ & $-18.54 * *$ & 1.67 & 11.11 & 7.73 & -0.63 & - & - & - & - & - & - & - & - & - & - \\
\hline 12. & $\mathrm{~L} 2 \times \mathrm{T} 2$ & 14.94 & 7.79 & 6.15 & 2.35 & $7.64 *$ & 3.31 & 2.44 & 2.15 & - & 6.45 & - & - & - & - & - \\
\hline 13. & L3 $\times$ T2 & $48.56^{* *}$ & -0.10 & -4.11 & -12.44 & 6.64 & $43.37 * *$ & - & - & - & 1.64 & - & - & - & - & - \\
\hline 14. & $\mathrm{~L} 4 \times \mathrm{T} 2$ & 7.60 & -7.18 & -1.27 & -0.72 & -0.73 & 2.09 & - & - & - & - & - & - & - & - & - \\
\hline 15. & L5 $\times$ T2 & $52.16^{* *}$ & 4.87 & $22.40^{* *}$ & $45.44 * *$ & $29.32 * *$ & $49.50^{* *}$ & - & $20.43 *$ & $44.04 * *$ & $26.97 * *$ & - & - & - & - & - \\
\hline 16. & L6 $\times$ T2 & $40.07 * *$ & 8.28 & 8.05 & 7.15 & $15.09 * *$ & $29.45^{* *}$ & - & 6.47 & 3.62 & $13.72 * *$ & - & - & - & - & - \\
\hline 17. & L7 x T2 & -2.23 & $-14.16^{* *}$ & 9.45 & 4.50 & -1.12 & - & - & 1.85 & 2.89 & - & - & - & - & - & - \\
\hline 18. & L8 $\times$ T2 & -8.18 & -2.47 & $20.90^{* *}$ & $16.75^{*}$ & 5.82 & - & - & 15.05 & 11.65 & 0.00 & - & - & - & - & - \\
\hline 19. & L9 $\times$ T2 & -0.11 & -3.12 & 35.56 ** & $19.68^{*}$ & $12.16^{* *}$ & - & - & $31.18 * *$ & 10.64 & 11.19 ** & - & - & - & - & - \\
\hline 20. & $\mathrm{~L} 10 \times \mathrm{T}_{2}^{2}$ & $21.25^{* *}$ & $12.83^{*}$ & 2.82 & 2.15 & $9.83 * *$ & 9.38 & 1.92 & - & - & 6.44 & - & - & - & - & - \\
\hline 21. & L1 $x$ T3 & -6.07 & $32.04 * *$ & $51.38^{* * *}$ & $48.13 * *$ & $28.87 * *$ & - & 4.94 & $22.32 * *$ & $14.48^{*}$ & $10.31 * *$ & - & - & 7.03 & 2.60 & 0.19 \\
\hline 22. & L2 $\times$ T3 & $32.52^{* *}$ & $30.64 * *$ & $25.25^{* *}$ & -10.40 & $18.99 * *$ & $21.55^{* *}$ & $17.44 * *$ & 10.71 & - & $6.67 *$ & - & 5.40 & - & - & - \\
\hline 23. & L3 $x$ T3 & $52.76^{* * *}$ & $58.70^{* * *}$ & $28.73 * *$ & $37.57 * *$ & $44.77 * *$ & $31.03 * *$ & $35.80^{* * *}$ & 11.61 & $13.87 *$ & $23.24 * *$ & 1.33 & $21.88 * *$ & - & 2.05 & $11.93 * *$ \\
\hline 24. & L4 $\times$ T3 & $50.69^{* *}$ & 4.80 & $37.85^{* *}$ & $47.35^{* *}$ & $34.71 * *$ & $31.21^{* *}$ & - & 8.93 & $14.33^{*}$ & $9.57 * *$ & 1.47 & - & - & 2.46 & - \\
\hline 25. & L5 $x$ T3 & $47.96^{* * *}$ & $46.52^{* *}$ & 12.87 & -6.36 & $25.06 * *$ & $25.00^{* *}$ & $31.48^{* * *}$ & 1.79 & - & $9.25^{* *}$ & - & $18.01 * *$ & - & - & - \\
\hline 26. & L6 $x$ T3 & $43.96^{* *}$ & $36.00^{* *}$ & $38.59 * *$ & -1.92 & $28.88^{* *}$ & $28.45^{* *}$ & $18.06^{* * *}$ & $28.57 * *$ & - & $13.22 * *$ & - & 5.96 & $12.50 *$ & - & 2.82 \\
\hline 27. & L7 $x$ T3 & $14.07 * *$ & $34.55^{* *}$ & 11.82 & $28.31 * *$ & $22.14 * *$ & 2.04 & $25.00 * *$ & 9.82 & 11.59 & $18.94 * *$ & 0.00 & $12.19 *$ & - & 0.00 & $8.03 * *$ \\
\hline 28. & L8 $\times$ T3 & -2.63 & $26.24 * *$ & $32.65^{* *}$ & $29.46 * *$ & $20.27 * *$ & - & 9.88 & $16.07^{*}$ & $15.55^{*}$ & $12.52 * *$ & - & - & 1.56 & 3.55 & 2.19 \\
\hline 29. & L9 $\times$ T3 & 9.33 & 3.45 & 5.53 & 5.59 & 5.99 & 6.03 & - & - & - & - & - & - & - & - & - \\
\hline 30. & $\mathrm{~L} 10 \times \mathrm{T}$ : & -6.60 & $12.51 *$ & $36.73^{* *}$ & $51.45^{* *}$ & $23.21 * *$ & - & - & $19.64 * *$ & $23.63 * *$ & $6.42 *$ & - & - & 4.69 & 10.79 & - \\
\hline
\end{tabular}

** Significant at 5 and 1 per cent, respectively. 


\section{Int.J.Curr.Microbiol.App.Sci (2017) 6(5): 990-1014}

Table.4 Heterosis for green fodder yield

\begin{tabular}{|c|c|c|c|c|c|c|c|c|c|c|c|c|c|}
\hline \multirow[t]{2}{*}{ S. No. } & \multirow[t]{2}{*}{ Crosses } & \multicolumn{4}{|c|}{ Heterosis } & \multicolumn{4}{|c|}{ Heterobeltiosis } & \multicolumn{4}{|c|}{ Economic Heterosis } \\
\hline & & E1 & $\mathbf{E 2}$ & E3 & E4 & E1 & E2 & $\mathbf{E 3}$ & $\mathbf{E 4}$ & E1 & E2 & $\mathbf{E 3}$ & E4 \\
\hline 1. & L1 $\quad x$ T1 & $68.76^{* * *}$ & $-53.99 * *$ & $-16.44 *$ & $20.98^{*}$ & $44.58^{* * *}$ & - & - & 4.85 & - & - & - & - \\
\hline 2. & L2 $x$ T1 & -12.12 & $-53.40 * *$ & $-16.44 * *$ & -3.59 & - & - & - & - & - & - & - & - \\
\hline 3. & L3 $x$ T1 & $27.15^{* * *}$ & $-58.35^{* *}$ & $-30.22 * *$ & -2.09 & $18.50^{* * *}$ & - & - & - & - & - & - & - \\
\hline 4. & L4 $\times$ T1 & 5.24 & $-44.35 * *$ & $-21.41^{* *}$ & $24.87 *$ & - & - & - & 3.90 & - & - & - & - \\
\hline 5. & L5 $\mathrm{x} \mathrm{T1}$ & 12.54 & 2.00 & $19.88 * *$ & 13.53 & - & - & - & - & - & - & - & - \\
\hline 6. & L6 $x$ T1 & $-26.93 * *$ & $-57.23 * *$ & $-41.78 * *$ & 4.91 & - & - & - & - & - & - & - & - \\
\hline 7. & L7 x T1 & $-49.84 * *$ & $-16.32 * *$ & $-24.69 * *$ & -14.96 & - & - & - & - & - & - & - & - \\
\hline 8. & L8 $\times \mathrm{T} 1$ & 3.50 & $-36.61 * *$ & $-41.64 * *$ & -14.12 & - & - & - & - & - & - & - & - \\
\hline 9. & L9 $\times$ T1 & $103.85^{* *}$ & $-46.75 * *$ & $-13.94 *$ & -17.38 & $63.29 * *$ & - & - & - & - & - & - & - \\
\hline 10. & $\mathrm{~L} 10 \times \mathrm{T} 1$ & $19.05^{* *}$ & $-27.51 * *$ & $-21.53 * *$ & $-40.22 * *$ & - & - & - & - & - & - & - & - \\
\hline 11. & L1 $\times$ T2 & $36.82 * *$ & -2.74 & 6.94 & $74.61 * *$ & $25.61 * *$ & - & - & $63.99 * *$ & - & - & - & - \\
\hline 12. & L2 $\times$ T2 & $77.45^{* *}$ & $-32.54 * *$ & $22.05 * *$ & $32.22 * *$ & $37.05^{* *}$ & - & - & 15.89 & - & - & - & - \\
\hline 13. & L3 $\times$ T2 & $13.87 *$ & 5.83 & $-14.92 *$ & $-35.96 * *$ & - & - & - & - & - & - & - & - \\
\hline 14. & $\mathrm{~L} 4 \times \mathrm{T} 2$ & $-39.49 * *$ & $-16.55^{*}$ & $-31.30 * *$ & -23.49 & - & - & - & - & - & - & - & - \\
\hline 15. & L5 $\times$ T2 & $-20.17 *$ & $14.39^{*}$ & $-20.42 * *$ & $47.98 * *$ & - & - & - & $47.98 * *$ & - & - & - & - \\
\hline 16. & L6 $\times$ T2 & $38.22 * *$ & $-13.70 * *$ & $-37.02 * *$ & 9.49 & $24.65^{* *}$ & - & - & 0.00 & - & - & - & - \\
\hline 17. & L7 $\times$ T2 & $-39.64 * *$ & 2.67 & $-28.81 * *$ & -13.54 & - & - & - & - & - & - & - & - \\
\hline 18. & L8 $\times$ T2 & $-41.57 * *$ & $58.40 * *$ & $-25.27 * *$ & $65.98 * *$ & - & $24.96 * *$ & - & $39.63 * *$ & - & - & - & - \\
\hline 19. & L9 $x$ T2 & 2.90 & -10.28 & $-14.22 *$ & 16.21 & - & - & - & 14.47 & - & - & - & - \\
\hline 20. & $\mathrm{~L} 10 \times \mathrm{T} 2$ & -5.71 & 12.92 & $-34.38 * *$ & $-26.27 *$ & - & - & - & - & - & - & - & - \\
\hline 21. & L1 $\times$ T3 & $97.50 * *$ & $14.20 *$ & $21.52 * *$ & $20.04 *$ & 87.12 ** & - & - & 0.88 & - & - & - & - \\
\hline 22. & L2 $\times$ T3 & $48.60^{* *}$ & 10.17 & $26.05^{* *}$ & $41.85^{* *}$ & $17.61^{*}$ & - & - & $27.25 * *$ & - & - & - & 2.33 \\
\hline 23. & L3 $\times$ T3 & $22.68 * *$ & $100.71^{* *}$ & $12.48 *$ & 4.05 & 3.59 & $67.79 * *$ & - & - & - & $20.64 * *$ & - & - \\
\hline 24. & L4 $\times$ T3 & $-29.28 * *$ & $38.14 * *$ & -0.08 & 14.37 & - & 4.25 & - & - & - & - & - & - \\
\hline 25. & L5 $x$ T3 & $38.14 * *$ & $133.58 * *$ & 1.84 & $41.45^{* *}$ & $21.17^{*}$ & $76.36 * *$ & - & 13.02 & - & $26.81 * *$ & - & - \\
\hline 26. & L6 $x$ T3 & -7.52 & $-17.71 * *$ & $-42.24 * *$ & $-49.81 * *$ & - & - & - & - & - & - & - & - \\
\hline 27. & L7 $\times$ T3 & $12.80 *$ & $45.20^{* *}$ & -4.78 & $37.22 * *$ & - & $25.88 * *$ & - & - & - & - & - & - \\
\hline 28. & L8 $\times$ T3 & $-48.18 * *$ & $-21.32 * *$ & -4.14 & -7.54 & - & - & - & - & - & - & - & - \\
\hline 29. & L9 $\times$ T3 & -6.03 & $-19.24 * *$ & $-32.59 * *$ & $-46.00 * *$ & - & - & - & - & - & - & - & - \\
\hline 30. & L10 x T3 & $-15.31 * *$ & $134.65^{* *}$ & -2.73 & $29.21 * *$ & - & $59.58 * *$ & - & 10.77 & - & $14.75^{* *}$ & - & - \\
\hline
\end{tabular}

** Significant at 5 and 1 per cent, respectively. 
Int.J.Curr.Microbiol.App.Sci (2017) 6(5): 990-1014

Table.5 Heterosis for dry fodder yield

\begin{tabular}{|c|c|c|c|c|c|c|c|c|c|c|c|c|c|}
\hline \multirow[t]{2}{*}{ S. No. } & \multirow[t]{2}{*}{ Crosses } & \multicolumn{4}{|c|}{ Heterosis } & \multicolumn{4}{|c|}{ Heterobeltiosis } & \multicolumn{4}{|c|}{ Economic Heterosis } \\
\hline & & E1 & E2 & E3 & $\mathbf{E 4}$ & E1 & E2 & E3 & E4 & E1 & E2 & $\mathbf{E 3}$ & E4 \\
\hline 1. & L1 x T1 & $52.28 * *$ & $-51.00 * *$ & $23.23^{* * *}$ & 8.02 & $20.27 * *$ & - & 4.35 & - & - & - & - & - \\
\hline 2. & $\mathrm{~L} 2 \times \mathrm{T} 1$ & $-25.39 * *$ & $-52.63 * *$ & -2.56 & $49.11^{* *}$ & - & - & - & $26.85^{* *}$ & - & - & - & - \\
\hline 3. & $\mathrm{~L} 3 \times \mathrm{T} 1$ & $-57.80^{* *}$ & $-53.00 * *$ & $41.25^{* *}$ & $39.13^{* *}$ & - & - & $21.95^{*}$ & $22.74 * *$ & - & - & - & - \\
\hline 4. & $\mathrm{~L} 4 \times \mathrm{T} 1$ & $-27.86^{* *}$ & $-31.33^{* *}$ & $21.20^{*}$ & $70.56^{* *}$ & - & - & - & $46.03 * *$ & - & - & - & - \\
\hline 5. & L5 $\times$ T1 & $39.01 * *$ & $17.90 *$ & $55.31 * *$ & -10.28 & $17.72 * *$ & - & $30.23^{* *}$ & - & - & - & - & - \\
\hline 6. & L6 $\times \mathrm{T} 1$ & -2.91 & $-62.77 * *$ & $-26.69 * *$ & $51.76^{* *}$ & - & - & - & $24.11^{* *}$ & - & - & - & - \\
\hline 7. & L7 $x$ T1 & $-48.52 * *$ & $-35.13^{* *}$ & $-20.07 * *$ & $30.05^{* *}$ & - & - & - & $15.62 *$ & - & - & - & - \\
\hline 8. & L8 $\times$ T1 & $13.69 * *$ & $-38.73 * *$ & 15.05 & $-39.52 * *$ & 2.85 & - & 10.77 & - & - & - & - & - \\
\hline 9. & L9 $\times \mathrm{T} 1$ & $43.58^{* * *}$ & $-39.19 * *$ & 2.20 & 7.62 & $36.79 * *$ & - & - & - & - & - & - & - \\
\hline 10. & $\mathrm{~L} 10 \times \mathrm{T} 1$ & $10.03^{* *}$ & $-17.57 *$ & 8.30 & $-26.05^{* *}$ & 5.21 & - & - & - & - & - & - & - \\
\hline 11. & $\mathrm{~L} 1 \times \mathrm{T} 2$ & $64.86^{* *}$ & $-48.40 * *$ & $20.76^{*}$ & $28.29 * *$ & $51.30^{* *}$ & - & - & 8.90 & - & - & - & - \\
\hline 12. & $\mathrm{~L} 2 \times \mathrm{T} 2$ & $58.54^{* *}$ & $-40.50 * *$ & $27.08^{* *}$ & $54.47 * *$ & $40.69 * *$ & - & - & $35.91 * *$ & - & - & - & - \\
\hline 13. & $\mathrm{~L} 3 \times \mathrm{T} 2$ & $30.12^{* *}$ & $-14.24 *$ & -14.44 & $43.83^{* * *}$ & $23.54 * *$ & - & - & $31.45^{* *}$ & - & - & - & - \\
\hline 14. & $\mathrm{~L} 4 \times \mathrm{T} 2$ & $14.24 * *$ & $-44.10 * *$ & $-35.87 * *$ & -2.51 & - & - & - & - & - & - & - & - \\
\hline 15. & $\mathrm{~L} 5 \times \mathrm{T} 2$ & $-52.81 * *$ & $-32.22 * *$ & -11.89 & -9.57 & - & - & - & - & - & - & - & - \\
\hline 16. & L6 $\times$ T2 & 7.49 & $-48.63^{* *}$ & -12.56 & 7.56 & - & - & - & - & - & - & - & - \\
\hline 17. & L7 $\times$ T2 & -8.50 & $-40.38 * *$ & $-23.35^{* *}$ & $-33.33 * *$ & - & - & - & - & - & - & - & - \\
\hline 18. & $\mathrm{~L} 8 \times \mathrm{T} 2$ & $-25.27 * *$ & 10.77 & -10.87 & $-14.17 *$ & - & - & - & - & - & - & - & - \\
\hline 19. & L9 $\times$ T2 & $13.62 * *$ & -3.01 & $29.05^{* *}$ & -11.39 & 0.33 & - & 13.85 & - & - & - & - & - \\
\hline 20. & $\mathrm{~L} 10 \times \mathrm{T} 2$ & 0.34 & $63.43^{* * *}$ & $-58.01 * *$ & $35.31 * *$ & - & 1.18 & - & $28.49 * *$ & - & 1.18 & - & - \\
\hline 21. & L1 1 T3 & $51.48^{* *}$ & 9.62 & $61.14^{* *}$ & $13.70^{* * *}$ & $44.37 * *$ & - & $30.56^{* *}$ & 9.11 & - & - & 8.63 & - \\
\hline 22. & L2 $x$ T3 & $58.67^{* *}$ & $113.15^{* *}$ & 9.44 & $60.57 * *$ & $46.01 * *$ & $49.85^{* *}$ & - & $26.58^{* *}$ & - & $16.63^{* *}$ & - & 2.93 \\
\hline 23. & L3 $\times$ T3 & $34.47 * *$ & $95.40 * *$ & 15.60 & $22.54 * *$ & $22.96^{* *}$ & $41.67 * *$ & - & - & - & 10.26 & - & - \\
\hline 24. & L4 x T3 & $-34.90^{* *}$ & -3.94 & 9.93 & $28.98^{* * *}$ & - & - & - & 2.25 & - & - & - & - \\
\hline 25. & L5 $x$ T3 & $26.13^{* *}$ & $79.60^{* *}$ & $48.33^{* * *}$ & $13.77 *$ & $21.21 * *$ & $29.39^{* *}$ & $19.07 *$ & 6.08 & - & 0.71 & - & - \\
\hline 26. & L6 $x$ T3 & -2.53 & $68.95^{* *}$ & $14.02 *$ & $-28.11 * *$ & - & $61.38^{* *}$ & 12.89 & - & - & $37.97 * *$ & - & - \\
\hline 27. & L7 x T3 & $19.89^{* *}$ & $14.64^{*}$ & 4.08 & $-17.58^{* *}$ & 1.13 & - & - & - & - & - & - & - \\
\hline 28. & L8 $\times$ T3 & -6.32 & 12.82 & $17.33^{*}$ & $-16.44 * *$ & - & - & 7.22 & - & - & - & - & - \\
\hline 29. & L9 $\times$ T3 & $-48.10 * *$ & $-24.71 * *$ & $-37.62 * *$ & $-30.46^{* *}$ & - & - & - & - & - & - & - & - \\
\hline 30. & $\mathrm{~L} 10 \times \mathrm{T} 3$ & $16.26^{* *}$ & $75.87 * *$ & -0.93 & $23.96^{* *}$ & - & $14.85^{*}$ & - & 4.28 & - & - & - & - \\
\hline
\end{tabular}

** Significant at 5 and 1 per cent, respectively. 
Int.J.Curr.Microbiol.App.Sci (2017) 6(5): 990-1014

Table.6 Heterosis for ear head length

\begin{tabular}{|c|c|c|c|c|c|c|c|c|c|c|c|c|c|c|c|c|}
\hline \multirow{2}{*}{$\begin{array}{c}\text { S. } \\
\text { No. }\end{array}$} & \multirow[t]{2}{*}{ Crosses } & \multicolumn{5}{|c|}{ Heterosis } & \multicolumn{5}{|c|}{ Heterobeltiosis } & \multicolumn{5}{|c|}{ Economic Heterosis } \\
\hline & & E1 & $\mathbf{E 2}$ & E3 & $\mathbf{E 4}$ & Pool & E1 & E2 & E3 & E4 & pool & E1 & E2 & E3 & $\mathbf{E 4}$ & pool \\
\hline 1. & $\mathrm{~L} 1 \times \mathrm{T} 1$ & 1.35 & -0.63 & -8.54 & -5.62 & -3.54 & - & - & - & - & - & - & - & - & - & - \\
\hline 2. & $\mathrm{~L} 2 \times \mathrm{T} 1$ & -3.23 & -0.00 & $17.58^{* * *}$ & 3.74 & 4.94 & - & - & 5.94 & - & - & - & - & - & - & - \\
\hline 3. & L3 $x$ T1 & 9.55 & $-12.99 *$ & -3.66 & 2.35 & -1.09 & 1.18 & - & - & 0.00 & - & - & - & - & - & - \\
\hline 4. & $\mathrm{~L} 4 \times \mathrm{T} 1$ & 10.39 & 8.45 & $16.00^{* *}$ & $23.64 * *$ & $14.89^{* *}$ & 3.66 & 6.94 & 7.41 & $22.89^{* *}$ & $13.96^{* *}$ & - & - & - & - & - \\
\hline 5. & L5 $x$ T1 & $25.00^{* *}$ & $14.47 *$ & $15.29^{* *}$ & $13.29^{*}$ & $16.72^{* * *}$ & $25.00^{* *}$ & 4.60 & 10.11 & 8.89 & $11.54^{* *}$ & - & - & - & - & - \\
\hline 6. & L6 $\times$ T1 & $17.65^{* * *}$ & 1.28 & -3.49 & $21.21 * *$ & $8.98^{* *}$ & 11.11 & - & - & $20.48^{* *}$ & 4.14 & - & - & - & - & - \\
\hline 7. & L7 x T1 & 7.19 & $21.92^{* *}$ & $14.65^{* *}$ & $15.85^{*}$ & $14.84^{* * *}$ & 1.23 & $20.27 *$ & 11.11 & $14.46^{*}$ & $14.10^{* *}$ & - & - & - & - & - \\
\hline 8. & L8 $x$ T1 & 12.58 & 6.92 & -0.00 & 7.51 & $6.65^{*}$ & 7.59 & - & - & 3.33 & 1.77 & - & - & - & - & - \\
\hline 9. & L9 $\times$ T1 & 5.33 & 9.09 & $11.24 *$ & 5.06 & $7.77^{*}$ & 1.28 & 2.44 & 6.82 & 0.00 & 5.26 & - & - & - & - & - \\
\hline 10. & $\mathrm{~L} 10 \times \mathrm{T} 1$ & 5.00 & 4.70 & -2.96 & 10.69 & 4.24 & - & 1.30 & - & 6.02 & 0.91 & - & - & - & - & - \\
\hline 11. & $\mathrm{~L} 1 \times \mathrm{T} 2$ & 4.29 & 1.12 & -2.62 & -4.57 & -0.69 & - & - & - & - & - & - & - & - & - & - \\
\hline 12. & $\mathrm{~L} 2 \times \mathrm{T} 2$ & -1.18 & 3.83 & $-9.09 *$ & -1.94 & -2.34 & - & 3.26 & - & - & - & - & - & - & - & - \\
\hline 13. & $\mathrm{~L} 3 \times \mathrm{T} 2$ & 3.49 & $20.23^{* *}$ & $-12.04 * *$ & -7.94 & 0.41 & 2.30 & $14.29^{*}$ & - & - & - & - & 5.05 & - & - & - \\
\hline 14. & $\mathrm{~L} 4 \times \mathrm{T} 2$ & -4.14 & 5.59 & 2.82 & 0.00 & 1.01 & - & - & - & - & - & - & - & - & - & - \\
\hline 15. & L5 $x$ T2 & -3.14 & 5.62 & -5.58 & 0.00 & -0.83 & - & 3.30 & - & - & - & - & - & - & - & - \\
\hline 16. & L6 $x$ T2 & 4.76 & $-13.14 *$ & -2.51 & 2.17 & -2.20 & 1.15 & - & - & - & - & - & - & - & - & - \\
\hline 17. & L7 $x$ T2 & $27.38^{* * *}$ & 11.52 & 5.43 & -2.73 & $10.00^{* * *}$ & $22.99^{* *}$ & 1.10 & - & - & - & 9.18 & - & - & - & - \\
\hline 18. & L8 $\times$ T2 & 4.82 & 3.37 & 2.62 & 6.25 & 4.26 & 0.00 & 1.10 & - & 0.00 & - & - & - & - & - & - \\
\hline 19. & L9 $\times$ T2 & 0.61 & -1.73 & $-24.49 * *$ & 5.08 & $-5.77 *$ & - & - & - & - & - & - & - & - & - & - \\
\hline 20. & $\mathrm{~L} 10 \times \mathrm{T} 2$ & -10.86 & 7.14 & $-21.43^{* *}$ & 2.25 & $-6.28^{*}$ & - & - & - & - & - & - & - & - & - & - \\
\hline 21. & $\mathrm{~L} 1 \times \mathrm{T} 3$ & $12.66^{*}$ & 6.51 & $10.59^{*}$ & -2.76 & $6.49^{*}$ & 8.54 & 3.45 & 8.05 & - & 5.87 & - & - & - & - & - \\
\hline 22. & $\mathrm{~L} 2 \times \mathrm{T} 3$ & -5.45 & 8.05 & -1.06 & -10.53 & -2.37 & - & 2.17 & - & - & - & - & - & - & - & - \\
\hline 23. & $\mathrm{~L} 3 \times \mathrm{T} 3$ & 8.98 & -3.66 & $14.12 * *$ & 0.58 & 5.04 & 7.06 & - & $11.49^{*}$ & 0.00 & 5.04 & - & - & - & - & - \\
\hline 24. & $\mathrm{~L} 4 \times \mathrm{T} 3$ & -4.88 & $14.47 *$ & 3.85 & 9.52 & 5.63 & - & 6.10 & - & 6.98 & 0.30 & - & - & - & - & - \\
\hline 25. & L5 x T3 & 10.39 & 6.51 & -2.27 & 4.55 & 4.59 & 3.66 & 3.45 & - & 2.22 & 4.44 & - & - & - & - & - \\
\hline 26. & L6 $x$ T3 & 9.20 & 1.20 & 2.25 & 4.76 & 4.30 & 8.54 & 0.00 & 0.00 & 2.33 & 4.14 & - & - & - & - & - \\
\hline 27. & $\mathrm{~L} 7 \times \mathrm{T} 3$ & $12.88^{*}$ & 1.28 & $27.61^{* *}$ & 6.59 & $12.17^{* * *}$ & 12.20 & - & $19.54 * *$ & 3.49 & $8.01^{*}$ & - & - & - & - & - \\
\hline 28. & L8 x T3 & 1.86 & 7.69 & 4.71 & 3.41 & 4.44 & 0.00 & 4.60 & 2.30 & 1.11 & 4.13 & - & - & - & - & - \\
\hline 29. & L9 $x$ T3 & -7.50 & -4.88 & $-9.71 *$ & -3.11 & $-6.36^{*}$ & - & - & - & - & - & - & - & - & - & - \\
\hline 30. & L10 x T3 & $-16.47 * *$ & 10.69 & -0.57 & -1.23 & -2.10 & - & 7.32 & - & - & - & - & - & - & - & - \\
\hline
\end{tabular}




\section{Int.J.Curr.Microbiol.App.Sci (2017) 6(5): 990-1014}

Table.7 Heterosis for number of primaries per plant

\begin{tabular}{|c|c|c|c|c|c|c|c|c|c|c|c|c|c|}
\hline \multirow[t]{2}{*}{ S. No. } & \multirow[t]{2}{*}{ Crosses } & \multicolumn{4}{|c|}{ Heterosis } & \multicolumn{4}{|c|}{ Heterobeltiosis } & \multicolumn{4}{|c|}{ Economic Heterosis } \\
\hline & & E1 & E2 & E3 & E4 & E1 & E2 & E3 & E4 & E1 & E2 & E3 & E4 \\
\hline 1. & L1 x T1 & $15.38^{*}$ & -1.20 & 7.64 & $44.27 * *$ & 13.21 & - & - & $23.94 * *$ & - & - & - & - \\
\hline 2. & $\mathrm{~L} 2 \times \mathrm{T} 1$ & $-40.64 * *$ & -11.92 & -15.56 & 14.59 & - & - & - & 12.77 & - & - & - & - \\
\hline 3. & L3 $x$ T1 & -6.78 & $-27.79 * *$ & $-30.59 * *$ & 5.76 & - & - & - & 4.12 & - & - & - & - \\
\hline 4. & $\mathrm{~L} 4 \times \mathrm{T} 1$ & $18.37 * *$ & $22.25^{* *}$ & 16.86 & 2.04 & 6.84 & - & 16.86 & - & - & - & - & - \\
\hline 5. & L5 $x$ T1 & $37.44 * *$ & -9.50 & $78.42^{* *}$ & $77.62 * *$ & 1.96 & - & $25.00 *$ & $30.85^{* * *}$ & - & - & - & - \\
\hline 6. & L6 $x$ T1 & $17.34 *$ & $-37.31 * *$ & 4.82 & 12.89 & 3.92 & - & - & 9.50 & - & - & - & - \\
\hline 7. & L7 x T1 & $-29.89 * *$ & $-16.71 * *$ & 21.07 & 4.29 & - & - & - & - & - & - & - & - \\
\hline 8. & $\mathrm{~L} 8 \times \mathrm{T} 1$ & $21.89^{* *}$ & $-18.27 * *$ & 6.98 & $25.61^{*}$ & 11.35 & - & 6.98 & - & - & - & - & - \\
\hline 9. & L9 $\times$ T1 & $28.77 * *$ & -10.47 & 3.79 & -7.20 & $22.88 * *$ & - & 3.49 & - & - & - & - & - \\
\hline 10. & $\mathrm{~L} 10 \times \mathrm{T} 1$ & -6.33 & 4.62 & -7.93 & 6.62 & - & - & - & - & - & - & - & - \\
\hline 11. & $\mathrm{~L} 1 \times \mathrm{T} 2$ & 8.17 & -0.68 & 0.66 & $41.22 * *$ & - & - & - & $36.81^{* * *}$ & - & - & - & - \\
\hline 12. & $\mathrm{~L} 2 \times \mathrm{T} 2$ & $23.31 * *$ & -6.99 & $-21.97 *$ & 1.84 & 2.55 & - & - & - & - & - & - & - \\
\hline 13. & $\mathrm{~L} 3 \times \mathrm{T} 2$ & $-24.61 * *$ & $-20.27 *$ & -11.52 & 4.14 & - & - & - & - & - & - & - & - \\
\hline 14. & $\mathrm{~L} 4 \times \mathrm{T} 2$ & $-17.10 * *$ & $75.65^{* *}$ & -8.98 & -4.60 & - & $33.77^{* *}$ & - & - & - & - & - & - \\
\hline 15. & L5 $\times$ T2 & $-20.74 * *$ & $58.80 * *$ & $62.77 * *$ & $127.47 * *$ & - & $22.52^{*}$ & 16.05 & $84.03 * *$ & - & - & - & 0.38 \\
\hline 16. & L6 x T2 & $26.11 * *$ & $-15.24 *$ & 5.65 & 3.49 & 1.02 & - & - & - & - & - & - & - \\
\hline 17. & L7 x T2 & $-23.27 * *$ & -3.47 & $38.65^{* *}$ & -14.41 & - & - & 7.41 & - & - & - & - & - \\
\hline 18. & L8 $\times$ T2 & $-18.64 * *$ & 11.34 & -8.98 & $45.23 * *$ & - & 7.28 & - & 21.53 & - & - & - & - \\
\hline 19. & L9 $\times$ T2 & $-27.76^{* *}$ & -8.17 & $21.32 *$ & -10.57 & - & - & 18.13 & - & - & - & - & - \\
\hline 20. & $\mathrm{~L} 10 \times \mathrm{T} 2$ & $-40.95 * *$ & $60.84 * *$ & $-28.30 * *$ & $31.87 * *$ & - & $52.32^{* *}$ & - & $25.00^{*}$ & - & - & - & - \\
\hline 21. & L1 x T3 & $32.20 * *$ & $28.70^{* *}$ & -4.27 & $-14.29 *$ & $22.64 * *$ & 8.82 & - & - & - & - & - & - \\
\hline 22. & $\mathrm{~L} 2 \times \mathrm{T} 3$ & 10.53 & -12.68 & -15.34 & -4.93 & 8.09 & - & - & - & - & - & - & - \\
\hline 23. & L3 $x$ T3 & $14.29 *$ & 0.29 & 3.98 & $-22.27 * *$ & - & - & - & - & - & - & - & - \\
\hline 24. & $\mathrm{~L} 4 \times \mathrm{T} 3$ & $-14.72 *$ & $42.76^{* * *}$ & -6.04 & -1.71 & - & - & - & - & - & - & - & - \\
\hline 25. & L5 $x$ T3 & 14.29 & $45.45^{* *}$ & $62.59^{* *}$ & $24.65^{* *}$ & - & 1.96 & 8.13 & - & - & - & 1.80 & - \\
\hline 26. & L6 $x$ T3 & $59.06^{* * *}$ & -5.51 & 8.62 & $-14.66^{*}$ & $48.53^{* *}$ & - & - & - & - & - & - & - \\
\hline 27. & L7 x T3 & $-40.79 * *$ & $-27.27 * *$ & $24.16^{*}$ & 6.74 & - & - & - & - & - & - & - & - \\
\hline 28. & L8 $x$ T3 & -9.66 & -3.49 & 4.46 & 11.91 & - & - & - & - & - & - & - & - \\
\hline 29. & L9 $\times$ T3 & $-25.09 * *$ & $-29.68 * *$ & $-28.42 * *$ & $-24.17 * *$ & - & - & - & - & - & - & - & - \\
\hline 30. & $\mathrm{~L} 10 \times \mathrm{T} 3$ & $-25.08 * *$ & $-17.40^{*}$ & -10.68 & -12.98 & - & - & - & - & - & - & - & - \\
\hline
\end{tabular}

** Significant at 5 and 1 per cent, respectively. 
Int.J.Curr.Microbiol.App.Sci (2017) 6(5): 990-1014

Table.8 Heterosis for Number of seeds per primary

\begin{tabular}{|c|c|c|c|c|c|c|c|c|c|c|c|c|c|}
\hline \multirow{2}{*}{$\begin{array}{c}\text { S. } \\
\text { No. }\end{array}$} & \multirow[t]{2}{*}{ Crosses } & \multicolumn{4}{|c|}{ Heterosis } & \multicolumn{4}{|c|}{ Heterobeltiosis } & \multicolumn{4}{|c|}{ Economic Heterosis } \\
\hline & & E1 & E2 & $\mathbf{E 3}$ & E4 & E1 & E2 & E3 & E4 & E1 & E2 & E3 & E4 \\
\hline 1. & L1 $x$ T1 & $26.96^{*}$ & $18.72 * *$ & $-24.84 * *$ & 0.43 & 19.67 & - & - & - & - & - & - & - \\
\hline 2. & $\mathrm{~L} 2 \times \mathrm{T} 1$ & $-38.62 * *$ & $-54.69 * *$ & $26.54 * *$ & $-14.06^{*}$ & - & - & $19.68 *$ & - & - & - & $19.68 *$ & - \\
\hline 3. & L3 $x$ T1 & $-19.36 * *$ & $-48.56 * *$ & $-28.78 * *$ & $-33.90 * *$ & - & - & - & - & - & - & - & - \\
\hline 4. & L4 $\times$ T1 & -14.29 & 1.20 & $-19.78^{*}$ & $-22.98 * *$ & - & - & - & - & - & - & - & - \\
\hline 5. & L5 $x$ T1 & 22.61 & $-30.07 * *$ & $-20.82 * *$ & 12.53 & - & - & - & - & - & - & - & - \\
\hline 6. & L6 $\times$ T1 & $36.54 * *$ & $-23.66 * *$ & $16.07 *$ & -5.57 & $31.48 *$ & - & - & - & - & - & - & - \\
\hline 7. & L7 $\times$ T1 & 14.81 & $19.80 * *$ & 11.73 & $-33.77 * *$ & 14.81 & 0.00 & - & - & - & 0.00 & - & - \\
\hline 8. & L8 $\times$ T1 & $155.27 * *$ & $14.48 * *$ & $-41.88^{* *}$ & -3.23 & $137.04 * *$ & 3.27 & - & - & $11.72 *$ & 3.27 & - & - \\
\hline 9. & L9 $\times$ T1 & $147.13^{* *}$ & $-30.41 * *$ & $-25.00 * *$ & -12.02 & $142.01 * *$ & - & - & - & 2.00 & - & - & - \\
\hline 10. & $\mathrm{~L} 10 \times \mathrm{T} 1$ & $100.00^{* *}$ & -10.82 & 7.12 & 7.49 & $83.94 * *$ & - & - & - & - & - & - & - \\
\hline 11. & $\mathrm{~L} 1 \times \mathrm{T} 2$ & $-56.91 * *$ & $-14.67 *$ & $-51.03^{* *}$ & $-17.49^{*}$ & - & - & - & - & - & - & - & - \\
\hline 12. & $\mathrm{~L} 2 \times \mathrm{T} 2$ & $17.36^{* *}$ & -9.80 & $29.38^{* * *}$ & $-18.47 * *$ & - & - & 13.06 & - & - & - & 0.80 & - \\
\hline 13. & L3 $\times$ T2 & $-24.84 * *$ & 10.48 & -8.87 & $-44.18^{* *}$ & - & 8.41 & - & - & - & - & - & - \\
\hline 14. & $\mathrm{~L} 4 \times \mathrm{T} 2$ & $67.27 * *$ & $-26.42 * *$ & $142.75^{* *}$ & $-28.36^{* * *}$ & $41.94 * *$ & - & $101.81^{* *}$ & - & $27.43^{* *}$ & - & $34.54 * *$ & - \\
\hline 15. & L5 $x$ T2 & $-28.54 * *$ & -10.58 & $28.26^{* * *}$ & -0.25 & - & - & 8.30 & - & - & - & 4.82 & - \\
\hline 16. & L6 $\times$ T2 & $27.06^{* *}$ & $16.07 * *$ & $61.08^{* *}$ & -4.37 & - & $13.08^{*}$ & $60.12^{* *}$ & - & - & - & 8.03 & - \\
\hline 17. & L7 $x$ T2 & -3.45 & $80.42^{* *}$ & $79.29 * *$ & $-18.91 *$ & - & $59.35^{* *}$ & $66.87 * *$ & - & - & $39.18^{* *}$ & 11.24 & - \\
\hline 18. & L8 $\times$ T2 & 4.55 & $13.38^{*}$ & 21.07 & -6.22 & - & 8.88 & 9.04 & - & - & - & - & - \\
\hline 19. & L9 $\times$ T2 & $-17.58^{*}$ & -2.11 & $27.02 *$ & $18.41 *$ & - & - & 9.04 & - & - & - & - & - \\
\hline 20. & $\mathrm{~L} 10 \times \mathrm{T} 2$ & $-47.56^{* * *}$ & $31.09 * *$ & -11.49 & -6.70 & - & 9.35 & - & - & - & - & - & - \\
\hline 21. & L1 $x$ T3 & $-30.69 * *$ & 5.48 & $-18.09 *$ & $16.44 *$ & - & - & - & 4.80 & - & - & - & 0.77 \\
\hline 22. & L2 $x$ T3 & $-50.39 * *$ & 8.78 & $44.72 * *$ & $-15.14^{*}$ & - & 3.67 & $29.73 * *$ & - & - & 3.67 & $15.66^{*}$ & - \\
\hline 23. & L3 $x$ T3 & $-25.11 * *$ & -7.48 & $-44.21 * *$ & $-32.46 * *$ & - & - & - & - & - & - & - & - \\
\hline 24. & $\mathrm{~L} 4 \times \mathrm{T} 3$ & $56.12 * *$ & -4.06 & $138.46^{* *}$ & 9.09 & $44.26^{* *}$ & - & $93.75^{* *}$ & 3.20 & 6.48 & - & $36.95^{* * *}$ & - \\
\hline 25. & L5 $x$ T3 & 8.35 & $15.03 *$ & 15.11 & -5.79 & - & 0.00 & - & - & - & - & - & - \\
\hline 26. & L6 $x$ T3 & 3.59 & $-19.06^{* *}$ & 13.95 & $-36.22 * *$ & - & - & 11.36 & - & - & - & - & - \\
\hline 27. & L7 $x$ T3 & $95.20 * *$ & -10.88 & $28.53^{* *}$ & 8.80 & $51.01 * *$ & - & 16.48 & - & $11.47 *$ & - & - & - \\
\hline 28. & L8 $\times$ T3 & $-32.37 * *$ & $26.01 * *$ & $26.86^{*}$ & $-20.16 * *$ & - & $18.92^{* *}$ & 11.36 & - & - & 7.76 & - & - \\
\hline 29. & L9 $\times$ T3 & -11.83 & $13.40 *$ & 7.12 & $-47.29 * *$ & - & - & - & - & - & - & - & - \\
\hline 30. & L10 x T3 & $-53.37 * *$ & 6.30 & -3.27 & -4.51 & - & - & - & - & - & - & - & - \\
\hline
\end{tabular}


Int.J.Curr.Microbiol.App.Sci (2017) 6(5): 990-1014

Table.9 Heterosis for seed index

\begin{tabular}{|c|c|c|c|c|c|c|c|c|c|c|c|c|c|}
\hline \multirow[t]{2}{*}{ S. No. } & \multirow[t]{2}{*}{ Crosses } & \multicolumn{4}{|c|}{ Heterosis } & \multicolumn{4}{|c|}{ Heterobeltiosis } & \multicolumn{4}{|c|}{ Economic Heterosis } \\
\hline & & E1 & E2 & E3 & E4 & E1 & E2 & E3 & $\mathbf{E 4}$ & E1 & E2 & $\mathbf{E 3}$ & E4 \\
\hline 1. & L1 x T1 & $9.33 * *$ & $-5.44 *$ & $23.14 * *$ & 1.15 & 3.24 & - & $11.03^{*}$ & - & - & - & - & - \\
\hline 2. & $\mathrm{~L} 2 \times \mathrm{T} 1$ & 3.87 & $-14.06^{* *}$ & $13.41^{* *}$ & -1.73 & 2.92 & - & $13.26^{*}$ & - & - & - & - & - \\
\hline 3. & L3 $\times$ T1 & $-13.99 * *$ & $-21.55^{* *}$ & $25.37 * *$ & $14.38^{* *}$ & - & - & $23.74 * *$ & $13.17 * *$ & - & - & 8.35 & $7.69 * *$ \\
\hline 4. & L4 $\times$ T1 & $13.34 * *$ & 2.58 & 5.96 & $9.34 * *$ & $10.58^{*}$ & - & - & - & - & - & - & - \\
\hline 5. & L5 $x$ T1 & $19.88^{* *}$ & $17.16^{* *}$ & $-15.92 * *$ & $11.68^{* *}$ & $14.51^{* *}$ & 4.01 & - & $7.60 * *$ & - & - & - & 2.38 \\
\hline 6. & L6 $x$ T1 & $25.92 * *$ & $7.09^{* *}$ & $-9.45^{*}$ & 2.67 & $22.58^{* *}$ & 2.48 & - & - & - & - & - & - \\
\hline 7. & L7 x T1 & 6.92 & -2.06 & 1.24 & $-5.20 * *$ & 3.29 & - & - & - & - & - & - & - \\
\hline 8. & L8 $\times$ T1 & $20.69^{* *}$ & $-8.21 * *$ & -9.73 & $-12.78 * *$ & $17.69^{* *}$ & - & - & - & - & - & - & - \\
\hline 9. & L9 $\times$ T1 & 5.44 & $-14.95 * *$ & -3.27 & $-13.12 * *$ & 2.65 & - & - & - & - & - & - & - \\
\hline 10. & $\mathrm{~L} 10 \times \mathrm{T} 1$ & 5.52 & $14.43 * *$ & $13.99 * *$ & $-7.45^{* *}$ & - & - & 6.94 & - & - & - & - & - \\
\hline 11. & $\mathrm{~L} 1 \times \mathrm{T} 2$ & -0.94 & $-12.51 * *$ & $17.56^{* * *}$ & $3.47^{*}$ & - & - & $16.54 *$ & - & - & - & - & - \\
\hline 12. & $\mathrm{~L} 2 \times \mathrm{T} 2$ & $17.25^{* *}$ & $30.53 * *$ & 2.65 & 2.74 & $12.39^{* *}$ & $24.27 * *$ & - & 1.72 & - & - & - & - \\
\hline 13. & $\mathrm{~L} 3 \times \mathrm{T} 2$ & $-15.45^{* *}$ & $14.78^{* * *}$ & 1.59 & $27.56^{* * *}$ & - & - & - & $13.65^{* *}$ & - & - & - & $5.86^{* *}$ \\
\hline 14. & $\mathrm{~L} 4 \times \mathrm{T} 2$ & $7.34^{*}$ & -4.84 & $21.39^{* * *}$ & $13.67^{* * *}$ & 1.36 & - & $19.04 * *$ & $13.32^{* * *}$ & - & - & - & - \\
\hline 15. & L5 $x$ T2 & $7.35^{*}$ & $-8.93 * *$ & -3.26 & $-4.32^{*}$ & 5.98 & - & - & - & - & - & - & - \\
\hline 16. & L6 $x$ T2 & $8.47^{*}$ & $-11.16 * *$ & -3.84 & $13.53^{* *}$ & 7.73 & - & - & $6.75^{* *}$ & - & - & - & - \\
\hline 17. & L7 $\times$ T2 & $16.00^{* * *}$ & 0.60 & -5.88 & $12.91^{* *}$ & $15.87^{* * *}$ & 0.13 & - & $6.33^{* *}$ & - & - & - & - \\
\hline 18. & L8 $\times$ T2 & 0.74 & $27.16^{* *}$ & 3.64 & $21.85^{* *}$ & - & $19.83^{* *}$ & - & $15.23^{* *}$ & - & - & - & - \\
\hline 19. & L9 $\times$ T2 & $10.76^{* *}$ & $-11.32 * *$ & $36.53 * *$ & $10.76^{* * *}$ & $10.00^{*}$ & - & $34.82 * *$ & 0.00 & - & - & - & - \\
\hline 20. & $\mathrm{~L} 10 \times \mathrm{T} 2$ & -5.78 & $6.51^{*}$ & $13.13^{*}$ & $38.00^{* * *}$ & - & 3.22 & 9.34 & $30.03 * *$ & - & - & - & - \\
\hline 21. & L1 x T3 & $-9.46^{* *}$ & $20.11^{* *}$ & $38.82 * *$ & $19.37 * *$ & - & $11.27 * *$ & $34.90 * *$ & $10.61^{* *}$ & - & - & - & - \\
\hline 22. & L2 x T3 & 1.99 & $18.22 * *$ & $12.99 *$ & $35.05^{* * *}$ & - & $17.72 * *$ & 4.73 & $34.39 * *$ & - & - & - & 0.82 \\
\hline 23. & L3 $\times$ T3 & $-8.64 * *$ & 4.63 & $26.10^{* * *}$ & $21.98^{* *}$ & - & - & $15.34 * *$ & $10.12^{* *}$ & - & - & 0.99 & 2.56 \\
\hline 24. & L4 x T3 & $-15.10 * *$ & $21.14 * *$ & $38.94 * *$ & $28.74 * *$ & - & $9.42 * *$ & $38.87 * *$ & $26.46^{* *}$ & - & - & 0.83 & - \\
\hline 25. & L5 x T3 & $-6.57 *$ & $25.11 * *$ & $14.65^{* *}$ & $27.80 * *$ & - & $24.72 * *$ & 5.54 & $18.26^{* *}$ & - & - & - & $4.30 * *$ \\
\hline 26. & L6 $x$ T3 & $-11.00 * *$ & $-10.71 * *$ & $-10.16^{*}$ & $-12.53 * *$ & - & - & - & - & - & - & - & - \\
\hline 27. & L7 x T3 & $6.79 *$ & 3.25 & -2.44 & $24.35^{* *}$ & - & - & - & $18.76^{* * *}$ & - & - & - & - \\
\hline 28. & L8 $\times$ T3 & -1.83 & $-11.75^{* *}$ & $16.43^{* * *}$ & $28.66^{* *}$ & - & - & $13.76^{*}$ & $23.40^{* *}$ & - & - & - & 0.82 \\
\hline 29. & L9 $\times$ T3 & -1.17 & $-17.85 * *$ & 6.53 & $16.81^{* *}$ & - & - & 3.13 & $6.88^{* *}$ & - & - & - & - \\
\hline 30. & $\mathrm{~L} 10 \times \mathrm{T} 3$ & $-8.09 * *$ & $27.70 * *$ & $19.46^{* * *}$ & $6.69^{* *}$ & - & $18.48^{* *}$ & $17.77 * *$ & - & - & - & - & - \\
\hline
\end{tabular}

** Significant at 5 and 1 per cent, respectively. 


\section{Int.J.Curr.Microbiol.App.Sci (2017) 6(5): 990-1014}

Table.10 Heterosis for harvest index

\begin{tabular}{|c|c|c|c|c|c|c|c|}
\hline \multirow[t]{2}{*}{ S. No. } & \multirow[t]{2}{*}{ Crosses } & \multicolumn{2}{|c|}{ Heterosis } & \multicolumn{2}{|c|}{ heterobeltiosis } & \multicolumn{2}{|c|}{ Economic Heterosis } \\
\hline & & E3 & E4 & E3 & $\mathbf{E 4}$ & E3 & $\mathbf{E 4}$ \\
\hline 1. & L1 $\mathrm{x} \mathrm{T1}$ & 2.92 & $-10.74 *$ & - & - & - & - \\
\hline 2. & $\mathrm{~L} 2 \times \mathrm{T} 1$ & $23.04 * *$ & $12.22 * *$ & 9.33 & $10.33^{*}$ & - & 0.44 \\
\hline 3. & L3 $x$ T1 & -8.80 & $-11.55^{*}$ & - & - & - & - \\
\hline 4. & $\mathrm{~L} 4 \times \mathrm{T} 1$ & 15.51 & -1.35 & 11.45 & - & - & - \\
\hline 5. & L5 $x$ T1 & $19.01^{* *}$ & 8.52 & 3.00 & 4.70 & - & - \\
\hline 6. & L6 $\times$ T1 & -0.23 & 2.97 & - & 2.41 & - & - \\
\hline 7. & L7 $x$ T1 & $25.31^{* *}$ & $17.14^{* *}$ & 14.61 & - & - & - \\
\hline 8. & L8 $\times$ T1 & 0.88 & $16.14^{* *}$ & - & 5.17 & - & - \\
\hline 9. & L9 $\times$ T1 & 2.58 & 3.54 & 0.64 & 3.49 & - & - \\
\hline 10. & $\mathrm{~L} 10 \times \mathrm{T} 1$ & $46.10^{* *}$ & 3.60 & $36.80 * *$ & - & 2.20 & - \\
\hline 11. & L1 $x$ T2 & -7.42 & $-14.24 * *$ & - & - & - & - \\
\hline 12. & L2 $\times$ T2 & 6.81 & -4.61 & - & - & - & - \\
\hline 13. & $\mathrm{~L} 3 \times \mathrm{T} 2$ & -12.81 & -2.88 & - & - & - & - \\
\hline 14. & $\mathrm{~L} 4 \times \mathrm{T} 2$ & $22.60 * *$ & -4.13 & 14.98 & - & - & - \\
\hline 15. & L5 $x$ T2 & $18.33^{*}$ & -2.86 & - & - & - & - \\
\hline 16. & L6 $x$ T2 & 8.76 & 3.39 & - & 2.28 & - & - \\
\hline 17. & L7 $x$ T2 & -4.82 & $15.46^{* *}$ & - & - & - & - \\
\hline 18. & L8 $\times$ T2 & 12.82 & $11.42^{*}$ & - & - & - & - \\
\hline 19. & L9 $\times$ T2 & -5.36 & -6.92 & - & - & - & - \\
\hline 20. & $\mathrm{~L} 10 \times \mathrm{T} 2$ & 9.34 & 3.71 & - & - & - & - \\
\hline 21. & $\mathrm{~L} 1 \times \mathrm{T} 3$ & $18.82 *$ & $-8.93^{*}$ & 0.27 & - & - & - \\
\hline 22. & L2 $x$ T3 & $-13.06^{*}$ & $-9.63^{*}$ & - & - & - & - \\
\hline 23. & L3 $\times$ T3 & $-53.75^{* *}$ & $-12.74 * *$ & - & - & - & - \\
\hline 24. & $\mathrm{~L} 4 \times \mathrm{T} 3$ & 0.49 & 0.50 & - & - & - & - \\
\hline 25. & L5 $x$ T3 & 3.90 & -4.27 & 2.88 & - & - & - \\
\hline 26. & L6 $x$ T3 & $-22.16^{* *}$ & $-11.56^{*}$ & - & - & - & - \\
\hline 27. & L7 $x$ T3 & -11.55 & $26.54 * *$ & - & 6.63 & - & - \\
\hline 28. & L8 $\times$ T3 & -7.78 & $11.30^{*}$ & - & 1.53 & - & - \\
\hline 29. & L9 $x$ T3 & $19.06^{* *}$ & -7.39 & 5.67 & - & - & - \\
\hline 30. & L10 x T3 & -7.89 & -5.55 & - & - & - & - \\
\hline
\end{tabular}


Int.J.Curr.Microbiol.App.Sci (2017) 6(5): 990-1014

Table.11 Heterosis for grain yield

\begin{tabular}{|c|c|c|c|c|c|c|c|c|c|c|c|c|c|}
\hline \multirow{2}{*}{$\begin{array}{c}\text { S. } \\
\text { No. }\end{array}$} & \multirow[t]{2}{*}{ Crosses } & \multicolumn{4}{|c|}{ Heterosis } & \multicolumn{4}{|c|}{ Heterobeltiosis } & \multicolumn{4}{|c|}{ Economic Heterosis } \\
\hline & & E1 & E2 & E3 & E4 & E1 & E2 & E3 & E4 & E1 & E2 & $\mathbf{E 3}$ & E4 \\
\hline 1. & $\mathrm{~L} 1 \times \mathrm{T} 1$ & $29.61 * *$ & -5.73 & $26.74 * *$ & $25.84 * *$ & 1.34 & - & 0.93 & $24.44 * *$ & - & - & - & - \\
\hline 2. & $\mathrm{~L} 2 \times \mathrm{T} 1$ & $-28.77 * *$ & $-52.42 * *$ & $75.59^{* *}$ & $-34.94 * *$ & - & - & $73.15^{* *}$ & - & - & - & - & - \\
\hline 3. & L3 $\times$ T1 & $46.82 * *$ & $35.37 * *$ & $11.30^{*}$ & $-36.36 * *$ & $31.54 * *$ & - & 4.92 & - & 2.62 & - & - & - \\
\hline 4. & $\mathrm{~L} 4 \times \mathrm{T} 1$ & -5.77 & $-38.94 * *$ & $61.36^{* *}$ & -1.12 & - & - & $31.48^{* *}$ & - & - & - & - & - \\
\hline 5. & L5 $\times$ T1 & $36.60 * *$ & 14.68 & $39.56^{* *}$ & $36.25 * *$ & $21.48^{* *}$ & - & $34.19^{* *}$ & $23.86^{* * *}$ & - & - & - & - \\
\hline 6. & L6 $\times$ T1 & $-19.82 * *$ & $-57.79 * *$ & $52.63^{* *}$ & $143.14 * *$ & - & - & $28.48^{* *}$ & $111.36^{* *}$ & - & - & 1.50 & - \\
\hline 7. & L7 $x$ T1 & $-52.08 * *$ & $-34.92 * *$ & $60.78^{* * *}$ & $128.97 * *$ & - & - & $51.85^{* *}$ & $88.64 * *$ & - & - & - & - \\
\hline 8. & L8 $\times$ T1 & 1.61 & $-49.24 * *$ & 3.45 & -7.95 & - & - & - & - & - & - & - & - \\
\hline 9. & L9 $\times$ T1 & 8.97 & $-41.07 * *$ & $33.68^{* *}$ & $67.88^{* *}$ & 6.04 & - & $17.59^{* *}$ & $30.68^{* *}$ & - & - & - & - \\
\hline 10. & L10 x T1 & -8.98 & 5.61 & $60.20^{* *}$ & $-24.05^{* *}$ & - & - & $45.37^{* *}$ & - & - & - & - & - \\
\hline 11. & $\mathrm{~L} 1 \times \mathrm{T} 2$ & $71.91^{* *}$ & -10.31 & 0.58 & $-10.77^{*}$ & $62.77^{* *}$ & - & - & - & - & - & - & - \\
\hline 12. & L2 $\times$ T2 & $98.78^{* *}$ & $-32.99 * *$ & $-11.32 *$ & $61.75^{* *}$ & $73.40^{* *}$ & - & - & $40.95^{* *}$ & - & - & - & - \\
\hline 13. & L3 $\times$ T2 & $54.72^{* *}$ & $25.51 * *$ & $-38.86^{* *}$ & 8.77 & $38.98^{* *}$ & - & - & - & - & - & - & - \\
\hline 14. & $\mathrm{~L} 4 \times \mathrm{T} 2$ & $24.51 * *$ & -19.17 & $23.43^{* *}$ & $-50.77 * *$ & - & - & 0.93 & - & - & - & - & - \\
\hline 15. & L5 $x$ T2 & $-56.19 * *$ & 1.62 & $29.46^{* *}$ & $-34.46 * *$ & - & - & $23.93^{* *}$ & - & - & - & - & - \\
\hline 16. & L6 $\times$ T2 & $37.04 * *$ & $-44.73 * *$ & -7.92 & $11.76^{*}$ & 18.09 & - & - & - & - & - & - & - \\
\hline 17. & L7 $x$ T2 & -3.00 & -15.98 & $25.12 * *$ & $-40.74 * *$ & - & - & $18.69^{* *}$ & - & - & - & - & - \\
\hline 18. & L8 $x$ T2 & $27.34 * *$ & $-18.37 * *$ & $18.61 * *$ & -3.63 & 0.62 & - & $10.48^{*}$ & - & - & - & - & - \\
\hline 19. & L9 $\times$ T2 & $27.66^{* *}$ & $-31.94 * *$ & $15.34 * *$ & $41.56^{\text {** }}$ & 6.38 & - & 1.87 & 3.81 & - & - & - & - \\
\hline 20. & $\mathrm{~L} 10 \times \mathrm{T} 2$ & -0.36 & $103.31 * *$ & $-25.13 * *$ & $41.71 * *$ & - & $35.29 * *$ & - & $18.10^{* *}$ & - & - & - & - \\
\hline 21. & L1 1 T3 & $50.49^{* *}$ & $251.38 * *$ & $62.30^{* *}$ & $-17.86^{* *}$ & $27.05^{* *}$ & $158.54 * *$ & $22.05^{* *}$ & - & - & $56.65^{* *}$ & - & - \\
\hline 22. & L2 $x$ T3 & $23.96^{* *}$ & $158.56^{* * *}$ & $26.72 * *$ & -2.24 & - & $90.24 * *$ & $15.75^{* *}$ & - & - & $15.27^{* *}$ & - & - \\
\hline 23. & L3 $x$ T3 & $17.50^{*}$ & $139.34 * *$ & $-33.33 * *$ & $-22.66 * *$ & $15.57 *$ & $78.05^{* * *}$ & - & - & - & 7.88 & - & - \\
\hline 24. & L4 $x$ T3 & $-22.81 * *$ & 2.22 & $23.08 * *$ & -0.71 & - & - & - & - & - & - & - & - \\
\hline 25. & L5 $x$ T3 & $17.65^{*}$ & $143.02 * *$ & 2.46 & $-12.21 * *$ & 14.75 & $69.92^{* *}$ & - & - & - & 2.96 & - & - \\
\hline 26. & L6 $x$ T3 & 0.00 & $86.26 * *$ & $-23.51 * *$ & $-56.08 * *$ & - & $75.54 * *$ & - & - & - & 20.20 ** & - & - \\
\hline 27. & L7 $x$ T3 & $17.24 * *$ & $40.78^{* *}$ & $41.70^{* *}$ & $-9.31^{*}$ & 10.07 & $17.89^{*}$ & $24.41^{* *}$ & - & - & - & - & - \\
\hline 28. & L8 $x$ T3 & $-21.83 * *$ & -2.49 & $29.88 * *$ & $-23.74 * *$ & - & - & $28.35^{* *}$ & - & - & - & - & - \\
\hline 29. & L9 $x$ T3 & $-53.61 * *$ & $-42.70 * *$ & 1.44 & 6.28 & - & - & - & - & - & - & - & - \\
\hline 30. & L10 x T3 & 10.10 & $82.14 * *$ & $-12.56^{*}$ & $-20.00 * *$ & - & $24.39 * *$ & - & - & - & - & - & - \\
\hline
\end{tabular}


Int.J.Curr.Microbiol.App.Sci (2017) 6(5): 990-1014

Table.12 Heterosis for protein content in grain

\begin{tabular}{|c|c|c|c|c|c|c|c|c|c|c|c|c|c|}
\hline \multirow[t]{2}{*}{ S. No. } & \multirow[t]{2}{*}{ Crosses } & \multicolumn{4}{|c|}{ Heterosis } & \multicolumn{4}{|c|}{ Heterobeltiosis } & \multicolumn{4}{|c|}{ Economic Heterosis } \\
\hline & & E1 & E2 & E3 & $\mathbf{E 4}$ & E1 & E2 & E3 & E4 & E1 & E2 & $\mathbf{E 3}$ & $\mathbf{E 4}$ \\
\hline 1. & L1 $x$ T1 & $-8.14 * *$ & $-3.31 *$ & $8.23^{*}$ & $-7.99 * *$ & - & - & 6.39 & - & - & - & - & - \\
\hline 2. & $\mathrm{~L} 2 \times \mathrm{T} 1$ & $-13.37 * *$ & $-12.36^{* *}$ & -4.22 & $-5.10 * *$ & - & - & - & - & - & - & - & - \\
\hline 3. & $\mathrm{~L} 3 \times \mathrm{T} 1$ & $-5.36^{*}$ & $11.91 * *$ & 4.16 & $13.64 * *$ & - & $6.31 * *$ & 1.58 & $10.40^{* *}$ & - & - & - & - \\
\hline 4. & $\mathrm{~L} 4 \times \mathrm{T} 1$ & $-13.05 * *$ & $-11.83 * *$ & $-12.64 * *$ & $-15.72 * *$ & - & - & - & - & - & - & - & - \\
\hline 5. & $\mathrm{~L} 5 \times \mathrm{T} 1$ & 3.40 & $-8.14^{* *}$ & -4.46 & $-17.39 * *$ & 1.88 & - & - & - & - & - & - & - \\
\hline 6. & L6 $x$ T1 & $-5.26^{*}$ & $-20.08 * *$ & $-22.96 * *$ & $-21.22 * *$ & - & - & - & - & - & - & - & - \\
\hline 7. & $\mathrm{~L} 7 \times \mathrm{T} 1$ & $12.87^{* * *}$ & $-14.95 * *$ & $-17.52 * *$ & $-13.12 * *$ & $5.30^{*}$ & - & - & - & - & - & - & - \\
\hline 8. & L8 $\times$ T1 & 0.15 & $-22.36 * *$ & $-20.30 * *$ & $-18.83^{* *}$ & - & - & - & - & - & - & - & - \\
\hline 9. & L9 $\times$ T1 & $-9.23^{* *}$ & $-16.68 * *$ & $-15.72 * *$ & $-15.54 * *$ & - & - & - & - & - & - & - & - \\
\hline 10. & $\mathrm{~L} 10 \times \mathrm{T} 1$ & $4.74 *$ & $18.43^{* *}$ & $14.03^{* *}$ & $12.61^{* *}$ & 0.61 & 0.32 & 0.61 & 1.12 & - & - & - & - \\
\hline 11. & L1 x T2 & $5.16^{*}$ & $7.27 * *$ & $15.08^{* *}$ & $-2.48 * *$ & - & 2.12 & $10.94 * *$ & - & - & 2.12 & $9.49 * *$ & - \\
\hline 12. & $\mathrm{~L} 2 \times \mathrm{T} 2$ & $-19.00 * *$ & $-29.67 * *$ & $-23.80 * *$ & $-23.08^{* *}$ & - & - & - & - & - & - & - & - \\
\hline 13. & $\mathrm{~L} 3 \times \mathrm{T} 2$ & $-18.89 * *$ & $-16.09 * *$ & $-25.29 * *$ & $-24.38^{* *}$ & - & - & - & - & - & - & - & - \\
\hline 14. & $\mathrm{~L} 4 \times \mathrm{T} 2$ & -3.70 & $-9.36 * *$ & $-11.34 * *$ & $-13.42 * *$ & - & - & - & - & - & - & - & - \\
\hline 15. & $\mathrm{~L} 5 \times \mathrm{T} 2$ & $-16.28 * *$ & $-33.21 * *$ & 0.48 & $-19.92 * *$ & - & - & - & - & - & - & - & - \\
\hline 16. & L6 $\times$ T2 & $-5.75^{*}$ & $-19.13^{* *}$ & $19.71 * *$ & $-12.26^{* *}$ & - & - & - & - & - & - & - & - \\
\hline 17. & L7 $\times$ T2 & $-9.55^{* *}$ & $-15.01 * *$ & $-20.22 * *$ & $-13.93 * *$ & - & - & - & - & - & - & - & - \\
\hline 18. & L8 $\times$ T2 & -1.13 & $-26.30^{* *}$ & $-25.72 * *$ & $-22.46^{* *}$ & - & - & - & - & - & - & - & - \\
\hline 19. & L9 $\times$ T2 & -0.56 & $-29.97 * *$ & $-23.19 * *$ & $-19.35^{* *}$ & - & - & - & - & - & - & - & - \\
\hline 20. & $\mathrm{~L} 10 \times \mathrm{T} 2$ & -4.32 & $17.69^{* *}$ & $10.30^{* *}$ & $7.22 * *$ & - & - & - & - & - & - & - & - \\
\hline 21. & L1 x T3 & $-14.90 * *$ & $-28.05^{* *}$ & $-24.59 * *$ & $-34.55^{* *}$ & - & - & - & - & - & - & - & - \\
\hline 22. & $\mathrm{~L} 2 \times \mathrm{T} 3$ & $12.23 * *$ & $-3.59^{*}$ & $-6.98^{*}$ & $-9.87 * *$ & 1.41 & - & - & - & 0.94 & - & - & - \\
\hline 23. & L3 $x$ T3 & $-16.31 * *$ & $4.60 * *$ & -1.48 & $-2.38 * *$ & - & 0.88 & - & - & - & - & - & - \\
\hline 24. & $\mathrm{~L} 4 \times \mathrm{T} 3$ & 2.46 & $-15.71 * *$ & $-20.92 * *$ & $-19.28 * *$ & - & - & - & - & - & - & - & - \\
\hline 25. & L5 $x$ T3 & $-8.92 * *$ & $-18.67 * *$ & $-22.63 * *$ & $-22.68^{* *}$ & - & - & - & - & - & - & - & - \\
\hline 26. & L6 x T3 & $-9.94 * *$ & $-6.84 * *$ & $-12.39 * *$ & $-11.11 * *$ & - & - & - & - & - & - & - & - \\
\hline 27. & L7 x T3 & 2.85 & $-15.78^{* *}$ & $-19.57 * *$ & $-18.98^{* *}$ & - & - & - & - & - & - & - & - \\
\hline 28. & L8 $\times$ T3 & $-9.18 * *$ & $-26.88 * *$ & $-13.76^{* *}$ & $-10.88^{* *}$ & - & - & - & - & - & - & - & - \\
\hline 29. & L9 $x$ T3 & $-11.69 * *$ & $-22.25 * *$ & $-22.18 * *$ & $-19.75^{* *}$ & - & - & - & - & - & - & - & - \\
\hline 30. & $\mathrm{~L} 10 \times \mathrm{T} 3$ & $-8.42 * *$ & $-14.04 * *$ & $-13.05^{* *}$ & $-15.01 * *$ & - & - & - & - & - & - & - & - \\
\hline
\end{tabular}

** Significant at 5 and 1 per cent, respectively. 
Int.J.Curr.Microbiol.App.Sci (2017) 6(5): 990-1014

Table.13 Heterosis for protein content in fodder

\begin{tabular}{|c|c|c|c|c|c|c|c|c|c|c|c|c|c|}
\hline \multirow[t]{2}{*}{ S. No. } & \multirow[t]{2}{*}{ Crosses } & \multicolumn{4}{|c|}{ Heterosis } & \multicolumn{4}{|c|}{ Heterobeltiosis } & \multicolumn{4}{|c|}{ Economic Heterosis } \\
\hline & & E1 & E2 & E3 & E4 & E1 & E2 & E3 & $\mathbf{E 4}$ & E1 & E2 & $\mathbf{E 3}$ & $\mathbf{E 4}$ \\
\hline 1. & L1 $x$ T1 & -0.12 & $6.00 * *$ & $5.43 * *$ & $5.23 * *$ & - & $3.03 * *$ & $4.23 * *$ & $3.69 * *$ & - & - & - & - \\
\hline 2. & $\mathrm{~L} 2 \times \mathrm{T} 1$ & $-7.23 * *$ & 1.01 & $1.94 *$ & $3.87 * *$ & - & 0.97 & 1.73 & $1.77 *$ & - & - & - & - \\
\hline 3. & L3 $\times$ T1 & -1.18 & $2.65^{* *}$ & $3.56^{* *}$ & $4.39 * *$ & - & - & 1.53 & $3.91 * *$ & - & - & - & - \\
\hline 4. & $\mathrm{~L} 4 \times \mathrm{T} 1$ & $-25.26^{* *}$ & $-5.59 * *$ & -1.86 & -0.79 & - & - & - & - & - & - & - & - \\
\hline 5. & L5 $x$ T1 & 2.72 & $-6.18 * *$ & $-6.14 * *$ & $-4.20 * *$ & - & - & - & - & - & - & - & - \\
\hline 6. & L6 $\times \mathrm{T} 1$ & $-10.00 * *$ & $-37.27 * *$ & $-32.69 * *$ & $-35.73 * *$ & - & - & - & - & - & - & - & - \\
\hline 7. & L7 x T1 & $20.82 * *$ & $26.32 * *$ & $27.76^{* *}$ & $31.55^{* *}$ & $10.73^{* *}$ & $7.22 * *$ & $9.21 * *$ & $13.96^{* *}$ & - & - & - & - \\
\hline 8. & $\mathrm{~L} 8 \times \mathrm{T} 1$ & $14.31^{* *}$ & $3.87 * *$ & $7.01^{* *}$ & $9.75 * *$ & $13.05^{* *}$ & $3.23 * *$ & $5.72 * *$ & $7.04 * *$ & - & - & - & - \\
\hline 9. & L9 $\times$ T1 & $-17.30 * *$ & $-10.87 * *$ & $-10.21 * *$ & $-9.04 * *$ & - & - & - & - & - & - & - & - \\
\hline 10. & $\mathrm{~L} 10 \times \mathrm{T} 1$ & $21.44 * *$ & $-9.15^{* *}$ & $-8.07 * *$ & $-6.66 * *$ & $20.65^{* *}$ & - & - & - & 1.76 & - & - & - \\
\hline 11. & $\mathrm{~L} 1 \times \mathrm{T} 2$ & -0.66 & -0.60 & -1.95 & $-2.57 * *$ & - & - & - & - & - & - & - & - \\
\hline 12. & $\mathrm{~L} 2 \times \mathrm{T} 2$ & $-19.76^{* *}$ & $-4.76^{* *}$ & $-2.98 * *$ & $-3.37 * *$ & - & - & - & - & - & - & - & - \\
\hline 13. & $\mathrm{~L} 3 \times \mathrm{T} 2$ & $11.97 * *$ & $4.96^{* *}$ & $5.17 * *$ & $4.81 * *$ & $7.97 * *$ & 0.60 & 0.00 & - & - & - & - & - \\
\hline 14. & $\mathrm{~L} 4 \times \mathrm{T} 2$ & -2.00 & $14.09^{* *}$ & $14.68^{* *}$ & $9.83 * *$ & - & $6.98^{* *}$ & $7.36^{* * *}$ & $2.67 * *$ & - & - & - & - \\
\hline 15. & L5 $\times$ T2 & $-23.98^{* *}$ & $-7.28 * *$ & $-6.31 * *$ & $-7.46^{* *}$ & - & - & - & - & - & - & - & - \\
\hline 16. & L6 $x$ T2 & $4.71 * *$ & $-16.21 * *$ & $-16.51^{* *}$ & $-15.39 * *$ & 1.18 & - & - & - & - & - & - & - \\
\hline 17. & $\mathrm{~L} 7 \times \mathrm{T} 2$ & $-8.64 * *$ & $27.33^{* *}$ & $27.78^{* *}$ & $28.47 * *$ & - & $15.13^{* *}$ & $16.23^{* *}$ & $16.52^{* *}$ & - & - & - & - \\
\hline 18. & $\mathrm{~L} 8 \times \mathrm{T} 2$ & $13.41 * *$ & $9.30^{* *}$ & $8.60 * *$ & $8.09^{* *}$ & $11.01^{* *}$ & 1.24 & 0.20 & 0.29 & - & - & - & - \\
\hline 19. & L9 $x$ T2 & $22.85^{* * *}$ & $-26.40 * *$ & $-25.00^{* * *}$ & $-25.12 * *$ & $21.61^{* *}$ & - & - & - & - & - & - & - \\
\hline 20. & $\mathrm{~L} 10 \times \mathrm{T} 2$ & -0.05 & $3.55^{* *}$ & $6.12 * *$ & $5.08^{* *}$ & - & - & 0.38 & - & - & - & - & - \\
\hline 21. & L1 $x$ T3 & $-23.83^{* *}$ & $-28.11 * *$ & $-28.03^{* *}$ & $-29.45^{* *}$ & - & - & - & - & - & - & - & - \\
\hline 22. & $\mathrm{~L} 2 \times \mathrm{T} 3$ & $25.12 * *$ & $9.37 * *$ & $10.55^{* *}$ & $9.02 * *$ & $14.10^{* *}$ & $5.04 * *$ & $6.62 * *$ & $5.20 * *$ & $8.34 * *$ & - & - & - \\
\hline 23. & L3 $x$ T3 & $-27.59 * *$ & $10.23^{* *}$ & $8.72 * *$ & $7.73^{* *}$ & - & $9.00^{* *}$ & $7.13 * *$ & $5.58 * *$ & - & - & - & - \\
\hline 24. & $\mathrm{~L} 4 \times \mathrm{T} 3$ & $26.38^{* *}$ & $-30.62 * *$ & $-28.49^{* *}$ & $-29.69^{* *}$ & $17.78^{* *}$ & - & - & - & $6.66^{* *}$ & - & - & - \\
\hline 25. & L5 $x$ T3 & $-10.61 * *$ & $-11.12 * *$ & $-10.65^{* *}$ & $-12.15^{* *}$ & - & - & - & - & - & - & - & - \\
\hline 26. & L6 $x$ T3 & $-20.19^{* *}$ & $-34.27 * *$ & $-33.33^{* *}$ & $-33.86^{* *}$ & - & - & - & - & - & - & - & - \\
\hline 27. & L7 $x$ T3 & $28.79 * *$ & $30.93 * *$ & $31.61 * *$ & $31.26^{* *}$ & $21.47^{* *}$ & $15.10^{* *}$ & $15.87^{* *}$ & $15.26^{* *}$ & - & - & - & - \\
\hline 28. & $\mathrm{~L} 8 \times \mathrm{T} 3$ & $-18.95^{* *}$ & $-26.12 * *$ & $-23.62 * *$ & $-24.56^{* *}$ & - & - & - & - & - & - & - & - \\
\hline 29. & L9 $x$ T3 & $-7.81 * *$ & 0.26 & 0.86 & -0.38 & - & - & - & - & - & - & - & - \\
\hline 30. & $\mathrm{~L} 10 \times \mathrm{T} 3$ & $-3.89 *$ & $-9.92 * *$ & $-9.79 * *$ & $-10.49^{* *}$ & - & - & - & - & - & - & - & - \\
\hline
\end{tabular}


The positive heterosis was significant for 15, 10,19 and 9 crosses in $E_{1}, E_{2}, E_{3}$ and $E_{4}$, respectively. The expression of grain yield depends upon the contribution of component traits and extent of their mutual cancellations. The crosses exhibited significant positive heterosis for grain yield in different environment, also exhibited significant heterosis for one or other characters like dry fodder yield, harvest index, number of primaries per plant, number of seeds per primary, protein content in grain and protein content in fodder. This indicates that component traits made significant contribution in expression of high heterosis for grain yield. Heterosis for grain yield along with heterosis for one or more yield component was also reported by EI-Shouny et al., (1990), Manikam and Das (1994), Ganesh et al., (1996), Ghorade et al., (1997), Navapour and Rezaie (1998), Salunke and Deore (1998), Swami (2000), Acharya (2000), Sharma (2002), Deora (2000) and Khandelwal (2003).

Out of these crosses, which exhibited significant positive heterosis for grain yield, heterobeltiosis was significant for 7, 8, 14 and 7 crosses in $E_{1}, E_{2}, E_{3}$ and $E_{4}$ respectively. The maximum value of heterobeltiosis was $73.40\left(\mathrm{~L}_{2} \times \mathrm{T}_{2}\right), 158.54\left(\mathrm{~L}_{1} \times \mathrm{T}_{3}\right), 73.15\left(\mathrm{~L}_{2} \times\right.$ $\left.\mathrm{T}_{1}\right)$ and 111.36 per cent $\left(\mathrm{L}_{6} \times \mathrm{T}_{1}\right)$ in $\mathrm{E}_{1}, \mathrm{E}_{2}, \mathrm{E}_{3}$ and $\mathrm{E}_{4}$, respectively. The crosses exhibited heterobeltiosis in more than one environment for grain yield were $\mathrm{L}_{5} \times \mathrm{T}_{1}, \mathrm{~L}_{6} \times \mathrm{T}_{1}, \mathrm{~L}_{7} \times \mathrm{T}_{1}$ and $L_{9} \times T_{1}$ in $E_{3}$ and $E_{4}$. Apart from these heterobeltiosis for other economically important characters in more than one environment were also observed i.e., for dry fodder yield in $\mathrm{L}_{5} \times \mathrm{T}_{1}, \mathrm{~L}_{2} \times \mathrm{T}_{2}, \mathrm{~L}_{3} \times \mathrm{T}_{2}, \mathrm{~L}_{2} \times$ $T_{3}$ and $L_{3} \times T_{3}$ in $E_{1}$ and $E_{3}$; for protein content in fodder in $\mathrm{L}_{7} \times \mathrm{T}_{1}, \mathrm{~L}_{2} \times \mathrm{T}_{3}$ and $\mathrm{L}_{7} \mathrm{x}$ $\mathrm{T}_{3}$ in all the four environments and $\mathrm{L}_{1} \times \mathrm{T}_{1}, \mathrm{~L}$ ${ }_{8} \times \mathrm{T}_{1}, \mathrm{~L}_{4} \times \mathrm{T}_{2}, \mathrm{~L}_{7} \times \mathrm{T}_{2}$ and $\mathrm{L}_{3} \times \mathrm{T}_{3}$ in $\mathrm{E}_{1}, \mathrm{E}_{2}$ and $\mathrm{E}_{3}$; for days to maturity $\mathrm{L}_{1} \times \mathrm{T}_{1}, \mathrm{~L}_{6} \mathrm{x}$ $\mathrm{T}_{1}, \mathrm{~L}_{7} \times \mathrm{T}_{1}, \mathrm{~L}_{8} \times \mathrm{T}_{1}, \mathrm{~L}_{10} \times \mathrm{T}_{2}, \mathrm{~L}_{1} \times \mathrm{T}_{3}, \mathrm{~L}_{4} \times$ $\mathrm{T}_{3}, \mathrm{~L}_{5} \times \mathrm{T}_{3}, \mathrm{~L}_{6} \times \mathrm{T}_{3}$ and $\mathrm{L}_{6} \times \mathrm{T}_{3}$ in all the four environments and for early flowering $\mathrm{L}_{4} \times \mathrm{T}_{1}$, $\mathrm{L}_{6} \times \mathrm{T}_{1}, \mathrm{~L}_{7} \times \mathrm{T}_{1}, \mathrm{~L}_{9} \times \mathrm{T}_{1}, \mathrm{~L}_{6} \times \mathrm{T}_{2}, \mathrm{~L}_{8} \times \mathrm{T}_{1}, \mathrm{~L}_{4}$ $\times \mathrm{T}_{2}, \mathrm{~L}_{6} \times \mathrm{T}_{2}, \mathrm{~L}_{8} \times \mathrm{T}_{2}, \mathrm{~L}_{4} \times \mathrm{T}_{2}, \mathrm{~L}_{7} \times \mathrm{T}_{3}$ and $\mathrm{L}_{8}$ $\mathrm{x} \mathrm{T}_{3}$ in $\mathrm{E}_{3}$.

In above heterobeltiotic crosses the economic heterosis was significant for nine characters in one or more environments but, different crosses exhibited economic heterosis for different characters. Maximum number of economic heterotic crosses were observed for days to flowering (17) followed by number of seeds per primary (8), plant height (6), grain yield (3), green fodder yield (3), seed index (3), dry fodder yield (2), protein content in fodder (2) and protein content in grain (1). The crosses exhibited economic heterosis in more than one environment were $\mathrm{L}_{8} \times \mathrm{T}_{1}$, in $E_{1}$ and $E_{3}$ and $L_{8} \times T_{2}$ in $E_{2}$ and $E_{3}$ for days to flowering; $L_{4} \times T_{2}$ in $E_{1}$ and $E_{3}$ for number of seeds per primary; $L_{3} \times T_{3}$ in $E_{2}$ and pool for plant height and $\mathrm{L}_{2} \times \mathrm{T}_{3}$ in $\mathrm{E}_{1}, \mathrm{E}_{2}$ and $\mathrm{E}_{3}, \mathrm{~L}_{4} \mathrm{x}$ $T_{3}$ in $E_{1}$ and $E_{3}, L_{5} \times T_{3}$ in $E_{2}$ and $E_{4}, L_{6} \times T_{3}$ in $E_{2}$ and $E_{3}$ and $L_{7} \times T_{3}$ in $E_{1}, E_{2}, E_{3}$ and pool for different characters. There were eight crosses exhibited economic heterosis for two characters in an environment viz., $\mathrm{L}_{2} \times \mathrm{T}_{1}$ $\left(\mathrm{E}_{3}\right), \mathrm{L}_{8} \times \mathrm{T}_{1}\left(\mathrm{E}_{1}\right), \mathrm{L}_{4} \times \mathrm{T}_{2}\left(\mathrm{E}_{1}\right)$ and $\mathrm{L}_{4} \times \mathrm{T}_{3}$ $\left(E_{3}\right)$ for days to flowering and number of seed per primary, $\mathrm{L}_{3} \times \mathrm{T}_{3}\left(\mathrm{E}_{2}\right)$ and $\mathrm{L}_{5} \times \mathrm{T}_{3}\left(\mathrm{E}_{2}\right)$ for plant height and green fodder yield and $\mathrm{L}_{2} \mathrm{x}$ $\mathrm{T}_{3}\left(\mathrm{E}_{2}\right), \mathrm{L}_{6} \times \mathrm{T}_{3}\left(\mathrm{E}_{2}\right)$ for grain yield and dry fodder yield. Cross $\mathrm{L}_{6} \times \mathrm{T}_{3}$ also exhibited economic heterosis for plant height and early flowering in $\mathrm{E}_{3}$. This indicates that for grain yield three crosses viz., $\mathrm{L}_{1} \times \mathrm{T}_{3}, \mathrm{~L}_{2} \times \mathrm{T}_{3}$ and $\mathrm{L}_{6}$ $\mathrm{x} \mathrm{T}_{3}$ exhibited economic heterosis out of them two crosses viz., $\mathrm{L}_{2} \times \mathrm{T}_{3}$ and $\mathrm{L}_{6} \times \mathrm{T}_{3}$ were also heterobeltiosis for dry fodder yield in $\mathrm{E}_{2}$ that is at spacing $30 \times 10 \mathrm{~cm}$. Apart from above crosses cross $\mathrm{L}_{6} \times \mathrm{T}_{3}$ had economic heterosis for days to $50 \%$ flowering and plant height in $E_{3}$ and for dry fodder yield in $E_{2}$ and $L_{2} \times T_{3}$ for dry fodder yield in $E_{2}$, protein content in fodder in $E_{1}$ and number of primaries per plant in $E_{3}$ may be utilized for these characters. 


\section{References}

Anonymous. 2015. Directorate of Agriculture, Govt. of Rajasthan, Jaipur, Rajasthan.

Anonymous. 2015. Agriculture Statistics At a Glance. Agriculture Statistics Division, Directorate of Economics and Statistics, Department of Agriculture and cooperation Ministry of Agriculture, Govt. of India, New Delhi.

Anonymous. 2015. FAOSTAT, Food and Agriculture Organization of the United Nations Statistics Division, Rome.

Doggett, H. 1988. Sorghum. Longman Scientific \& Technical, London Cereal Sci., 44: 236251.

Fisher, R.A. 1932. The Genetical Theory of Natural Selection. Clarendon, Oxford.

Fisher, R.A. and Yates, F. 1967. Statistical tables for biological, agricultural and medical research. Longman Group Limited, London.

Fonesca, S. and Patterson, F. 1968. Hybrid vigour in seven parent diallel in winter wheat (Triticum aestivum L). Crop Sci., 8: 85-95.

Ganesh, S., Khan, A.K.F and Senthil, N. 1996. Heterosis studies for grain yield characters in sweet sorghum. Madras Agri. J., 83: 655-657.

Hariprasanna, K., Rajendrakumar, P. and Patil, J.V. 2012. Parental selection for high heterosis in sorghum [Sorghum bicolor (L.) Moench]-combining ability, heterosis and their inter-relationships. Crop Res., 44: 3, 400-408. Heredity, 9: 223-228.

Kulakarni, V., Salimath, P.M and Patil, M.S. 2007. Combining ability analysis in rabi sorghum [Sorghum bicolor (L.) Moench]. Crop Res., 32(3): 455-458.

Meredith, W.R. and Bridge, R.R. 1972. Heterosis and gene action in cotton (Gossypium hirsutam. Crop Sci., 12: 304-310.
Murty, U.R. 1985. The concept of vybrid III. Stability of grain, biological and fodder yield of purelines, vybrids and hybrids in Sorghum bicolor (L.) Moench. Cereal Res. Communication, 13: 169-176.

Panse, V. G. and Sukhatme, P. V. 1985. Statistical Methods for Agricultural Workers. Indian Council of Agricultural Research, New Delhi.

Panse, V.G and Sukhatme, P.V. 1961. Statistical Methods. Oxford and IBH Publishers,

Salini, K., Satyanarayana Rao, V., Ramana, J.V and Srinivasa Rao, V. 2008. Line x tester analysis in dual purpose sorghum [Sorghum bicolor (L.) Moench]. The Andhra Agri. J., 55(2): 166-174.

Salunke, C.B. and Deore, G.N. 1998. Heterosis in rabi sorghum for grain yield and its. components. Madras Agri. J., 87 (1): 143144.

Sharma, H., and Sharma, G.S. and Dadheech, A. 2002. Heterosis for grain yield and its component traits in sorghum (Sorghum bicolor (L.) Moench. Ann. Agric. Res. New series, 24(3): 579-582.

Shull, G.H. 1914. Hybridization methods in corn breeding. American Breeder's Mav., 1: 98107. In: Heterosis (Gowen, J. W. Ed). Hafner Inc., New York, pp. 50.

Shull, G.H. 1914. Duplicate gene for capsule form in Capsella bursapustoris. Zeit Induk Abstr. V. Verbung. 12: 94-149. In "Heterosis" "Principle of Plant Breeding". R.W. Allard Ed.. Jhon Willey and sons. Inc., New York.

Umakanth, A.V., Rao, S.S and Kuriakose S.V. 2006. Heterosis in landrace hybrids of post rainy sorghum (Sorghum bicolor (L.) Moench). Indian J. Agri. Res., 40(2): 147150 .

\section{How to cite this article:}

Meena, B.L., B.R. Ranwah, S.P. Das, S.K. Meena, R. Kumari, Rumana Khan, V.K. Bhagasara and Gangarani Devi, A. 2017. Estimation of Heterosis, Heterobeltiosis and Economic Heterosis in Dual Purpose Sorghum [Sorghum bicolor (L.) Moench]. Int.J.Curr.Microbiol.App.Sci. 6(5): 990-1014. doi: https://doi.org/10.20546/ijcmas.2017.605.109 